\title{
1 Submarine glacial landforms record 2 Late Pleistocene ice-sheet dynamics, 3 Inner Hebrides, Scotland
}

4 Authors:

5 *Dayton Dove ${ }^{\text {a }}$ - British Geological Survey, Murchison House, West Mains Road, Edinburgh, EH9 3LA,

$6 \quad$ UK; 44 (0)131-650-0355; dayt@bgs.ac.uk

7 Riccardo Arosio ${ }^{b}$ - Scottish Association for Marine Science, Scottish Marine Institute, Oban, PA37

8 1QA, UK; 44 (0)1631 559 257; Riccardo.Arosio@sams.ac.uk.

9 Andrew Finlayson ${ }^{a}$ - British Geological Survey, Murchison House, West Mains Road, Edinburgh, EH9

10 3LA, UK; 44 (0)131-650-0355; afin@bgs.ac.uk.

11 Tom Bradwell ${ }^{\text {a,c }}$ - Biological and Environmental Sciences, University of Stirling, Stirling, FK9 4LA, UK;

1244 (0)1786467840; tom.bradwell@stir.ac.uk.

13 John Howe ${ }^{b}$ - Scottish Association for Marine Science, Scottish Marine Institute, Oban, PA37 1QA,

14 UK; 44 (0)1631 559 257; john.howe@sams.ac.uk.

$15 *$ Corresponding Author 


\section{Abstract}

We use $\sim 7,000 \mathrm{~km}^{2}$ of high-resolution swath bathymetry data to describe and map the submarine glacial geomorphology, and reconstruct Late Pleistocene ice sheet flow configurations and retreat dynamics within the Inner Hebrides, western Scotland. Frequently dominated by outcrops of structurally complex bedrock, the seabed also comprises numerous assemblages of well-preserved glacigenic landforms typical of grounded ice sheet flow and punctuated ice-margin retreat. The occurrence and character of the glacially streamlined landforms is controlled in part by the shallow geology and topography, however these factors alone cannot account for the location, orientation, and configuration of the observed landforms. We attribute the distribution of these elongate streamlined landforms to the onset zone of the former Hebrides Ice Stream (HIS) - part of a major ice stream system that drained 5-10\% of the last British-Irish Ice Sheet (BIIS). We suggest this geomorphic signature represents the transition from slow 'sheet flow' to 'streaming flow' as ice accelerated out from an environment characterized by numerous bedrock obstacles (e.g. islands, headlands), towards the smooth, sediment dominated shelf. The majority of streamlined landforms associated with the HIS indicate ice sheet flow to the southwest, with regional-scale topography clearly playing a major role in governing the configuration of flow. During maximal glacial conditions ( $27-23 \mathrm{ka})$ we infer that the HIS merged with the North Channel-Malin Shelf Ice Stream to form a composite ice stream system that ultimately reached the continental shelf edge at the BarraDonegal Trough-Mouth Fan. Taken collectively however, the pattern of landforms now preserved at seabed (e.g. convergent flow indicators, cross-cutting flow sets) is more indicative of a thinning ice mass, undergoing reorganization during overall ice sheet retreat (during latter stages of Late Weischselian glaciation). Suites of moraines overprinting the streamlined landforms suggest partial stabilization of the HIS prior to the ice sheet retreating to more isolated, topographically confined troughs and basins. Retreat from the shelf towards, and back into the Inner Hebrides may have been rapid due the prevalence of overdeepened troughs. Within the near-shore fjord-like troughs and deeps, basin-aligned streamlined landforms indicate the subsequent flow of thinner topographically partitioned ice masses, and overprinted moraines record further ice margin retreat, potentially along tide-water margins. This work provides the first geomorphological constraints for this large marineinfluenced sector of the former BIIS. We also shed new light on the glacial geomorphic record found at the transition from terrestrial to marine continental-shelf settings, and examine the interplay between substrate geology, bed topography/bathymetry, and grounding-line positions relationships which are important for characterizing contemporary marine ice sheet margins. 


\section{Introduction}

Empirically derived ice-sheet reconstructions based on the extant glacial landform record are important for refining and constraining glaciological models which can in turn help to explain oceanatmosphere-cryosphere interactions over millennial timescales (e.g. Boulton \& Hagdorn, 2006; Hubbard et al., 2009; Pollard \& De Conto, 2009). Ice streams are of particular interest within the glaciological system as they act as high flux corridors facilitating the discharge of the majority of an ice sheet's mass via a tributary network (e.g. Bamber et al., 2000; Truffer \& Echelmeyer, 2003; Bennett, 2003). Contemporary studies in West Antarctica show that these ice stream systems are undergoing rapid change, partly driven by the migration of grounding-line positions, which may fundamentally alter the ice sheet's dynamic behaviour within marine sectors (e.g. Favier et al., 2014).

Several major ice streams have been identified within the former (Pleistocene) British-Irish Ice Sheet (BIIS) based on a combination of onshore and offshore geomorphological mapping, although knowledge is still lacking for key marine sectors owing to a paucity of data. One such area is offshore the central west coast of Scotland discussed in this manuscript, stretching from Skye in the north to Islay in the south and encompassing the ice divide (or saddle) between the Scottish and Irish icemass centres (Figs. 1,2). Research on the glacial history of the west coast of Scotland spans back at least 150 years (Geikie, 1863), however detailed studies of past glaciation have been until recently, focused primarily on terrestrial observations and data (e.g. Gregory, 1927; Dawson, 1982; Sissons, 1983). Not surprisingly, the scarcity of suitable marine data has limited researchers' ability to characterize the incursion of ice into the marine realm. And while a detailed description of offshore Quaternary deposits alongside a seismo- stratigraphic framework was established for the Inner Hebrides by Binns et al. (1974) and Davies et al. (1984), this analysis pre-dated the more recent understanding of how ice streams govern ice-sheet drainage (e.g. Stokes and Clark, 2001), and of their impact on mass balance through dynamic binge/purge cycles (e.g. Hubbard et al., 2009).

It is the application of improved glaciological theory together with the increasing availability of highresolution marine geophysical data which has enabled researchers to more accurately reconstruct the extent and dynamics of glaciation on both currently (e.g. Jamieson et al., 2012), and formerly glaciated continental margins (e.g. Todd et al., 2007; Andreassen et al., 2008; Jakobsson et al., 2014). Bathymetry data in particular have been instrumental in advancing our understanding of marineoccupying ice sheets, particularly where acquired over extensive geographic areas. High-resolution swath bathymetry allows researchers to view the seabed as a continuous resolved surface $(\sim 50 \mathrm{~cm}$ $20 \mathrm{~m}$ horizontal resolution depending on depth) which may be interpreted using well-established geomorphological techniques (e.g. Clark, 1997; Hubbard and Glasser, 2005). Bathymetry data also 
bring further value to interpreting co-registered or legacy seismic and core data, where seabed morphology may draw attention to otherwise undescribed or unnoticed sub-seabed glacigenic features. As approximately two thirds of the BIIS was probably marine based during the Last Glacial Maximum (Clark et al., 2012), this approach is of increasing importance for understanding the glacial history in and around the British Isles.

While a large convergent flow system has been tentatively proposed for this sector of the BIIS (draining the high ground of NW Ireland, western Scotland and the Inner Hebrides, and terminating at a large Pleistocene sediment depocentre on the continental shelf - the Barra-Donegal Fan) (Fig. 1) (Stoker et al., 1994; Bradwell et al., 2008), these conceptual models have only recently been supported and refined by in situ data. Bathymetry and shallow seismic data have shed important new light on the ice-flow configuration in the region offshore NW Ireland and on the Malin Shelf (Dunlop et al., 2010; Ó Cofaigh et al., 2012) and further north in the Sea of the Hebrides (Howe et al., 2012).

This paper addresses a key data gap between Ireland and the Sea of the Hebrides, and in particular explores the transition zone from terrestrial to marine continental-shelf setting. By adopting a systematic geomorphological approach to map the seabed within the Inner Hebrides of western Scotland, we examine the glacial landform evidence revealed in a large bedrock-dominated area of seabed $\left(\sim 7,000 \mathrm{~km}^{2}\right)$; reconstruct the pattern of ice flow and deglaciation; and test recently proposed models of glaciation in this important marine-influenced ice-sheet sector (Fig. 2) (e.g. Finlayson et al., 2014; Dunlop et al., 2010)

\subsection{Setting}

Within the marine environment of the Inner Hebrides, the Quaternary stratigraphy has not been significantly revised since Davies et al. (1984), who utilized the first systematic geophysical and coring survey data around the Inner Hebrides. They observed several regionally persistent seismostratigraphic units overlying bedrock, that likely incorporate pre- Weichselian, Weichselian, and Holocene sediments (Fig. 3). Age control is poorly constrained in the region due to the scarcity of samples, and contamination by sediment reworking within the samples (from glacial, and more recent hydrodynamic regimes). The few existing radiocarbon dates from within glacigenic sediments come from a single seismostratigraphic unit, Jura Formation), and suggest deposition from Late Weichselian through to the Holocene ( 16 ka-10ka) (Harkness and Wilson, 1974; Peacock et al., 2012). Ages of older stratigraphic units were simply inferred by Davies et al. (1984), extrapolating down section using stratigraphic principles, and hypothesizing links to regional palaeoceanographic events. 
The acoustically well-layered Jura Formation is interpreted to have formed in dynamic glacimarine (possibly Younger Dryas) and marine setting, with notably fewer dropstones than the underlying

117 Barra Formation, which is acoustically distinct. The silty clays of the Barra Formation are interpreted to have accumulated rapidly following glacial recession, and are in turn underlain by the Hebrides Formation, a diamict interpreted as glacial till. This till unit was also recognized by Boulton et al. (1981), and is thin, discontinuous, and commonly preserved within localized structural basins. Of particular interest for understanding the glacial history of the region is a laterally extensive erosion surface which separates the Hebrides Formation from an underlying glacimarine unit termed the Stanton Formation. Davies et al. (1984) acknowledged that this erosional surface can be traced far onto the continental shelf, potentially indicating that Scottish mainland-sourced ice reached the shelf break during full glacial conditions. Despite also observing several large SW-NE oriented valleys cut further into underlying units, they instead preferred the interpretation that the majority of the ice flowed south towards the Irish Sea and English Midlands, reverting to results from terrestrial geomorphological studies (Sissons, 1983). Fyfe et al. (1993) applied this stratigraphic model as part of a regional mapping effort, but also importantly observed that the topography of the prominent erosion surface indicates that ice flowed southwest across the Inner Hebrides area. More recently, Howe et al. (2012) shed new light on the Davies et al. (1984) model by linking the proposed Quaternary stratigraphy to landform assemblages mapped from high-resolution swath bathymetry in the Sea of Hebrides, a subset of the data presented here. Observing an array of glacigenic landforms and large overdeepened basins, Howe et al. (2012) proposed that an ice stream drained a large sector of the western BIIS, flowing southwest before turning west around the Outer Hebridean platform towards the shelf break, and ultimately terminating at the Barra-Donegal Fan (Fig. 1). Using the geomorphic evidence available at the time, they postulated that the onset zone of this 'Hebrides Ice Stream' was located within the Inner Hebrides. While not analyzing new marine data, Finlayson et al.'s (2014) synthesis of glacial geomorphological data from SW Scotland and the North Channel has implications for BIIS dynamics within this important marine-influenced sector. They propose a sequence of events whereby ice flow switched from southward to westward and back, during various stages of Mid to Late Weichselian glaciation. Combining existing and new geomorphic constraints together with all available chronological data, this step-wise reconstruction utilizes the elevation of geomorphic observations to differentiate between key phases of ice-sheet flow and retreat within the region. Hebrides. Whilst there was a glaciologically independent ice cap occupying the Outer Hebrides (e.g. 
Stone and Ballantyne, 2006), it has been shown that the BIIS reached the continental shelf edge during the last glacial period, through a combination of studies employing core-seismic associations (e.g. Stoker, 1994; Serjup et al., 2005), geomorphology based on medium-resolution 'Olex' bathymetry (Bradwell et al., 2008; Clark et al., 2012), and palaeoceanographic studies investigating the occurrence of ice-rafted debris (IRD). Analysis of IRD in sediment cores is widely used as a proxy for the enhanced activity of a marine-terminating ice margin, although debates still surround key processes (e.g. the glaciodynamic processes that lead to calving events and their exact relationship with spikes in IRD production). Analysis of sediment cores adjacent to the former BIIS, from the Barra-Donegal Fan, used multiple IRD finger-printing techniques to identify which mineral components relate primarily to BIIS vs. Laurentide Ice Sheet iceberg delivery (e.g. Knutz et al. 2001; Scourse et al. 2009). These studies indicate that major growth of the BIIS occurred from $29 \mathrm{ka}$, reaching its maximum extent at $\sim 27 \mathrm{ka}$ (Fig. 1). Significant iceberg discharge events from the BIIS are recorded in IRD from 27 ka onwards, followed by a marked decrease from 23 ka (Knutz et al. 2001; Peck et al., 2007).

\section{Data and Methods}

In this study we utilize a large compilation of vessel-based swath bathymetry to map the glacial geomorphology of the seabed within the Inner Hebrides (Fig. 2). To further inform this mapping we analyse legacy BGS seismic data revealing the shallow sub-seabed. NEXTMap airborne radar data provide high-resolution topography data along the adjacent coast for context.

The vast majority of the $~ 7,000 \mathrm{~km}^{2}$ of near-continuous swath bathymetric coverage from Skye in the north to Mull of Kintyre in the south was acquired for the Maritime \& Coastguard Agency's (MCA) Civil Hydrography Programme (CHP). This forms part of an ongoing survey programme coordinated by the UK Hydrographic Office to update nautical charts, and improve safety at sea in UK waters (https://www.ukho.gov.uk/AboutUs/Pages/HydrographicNotes.aspx). The study area incorporates Hydrographic Instruction survey areas: 1257, 1297, 1298, 1299, 1329, 1362, 1354, 1364 , and 1371. Bathymetry surveys conducted on behalf of the CHP were acquired to the International Hydrographic Organisation (IHO) Order 1a from multiple vessels between 2008 and 2013, using several different echosounding transducers (both multibeam and interferometric systems). Post-acquisition data processing routines also varied by survey, however many contractors exploit the Combined Uncertainty and Bathymetry Estimator (CUBE) (Calder and Mayer, 2003) module within Caris HIPS and SIPS along with manual swath editing. Bathymetry data on the Canna High were acquired by the British Geological Survey (BGS) with the initial purpose of mapping 
We have compiled these bathymetric survey datasets and nominally gridded the data to $5 \mathrm{~m}$ resolution using QPS Fledermaus software, exporting to floating point geotifs. The bathymetry data were further stitched together with NEXTmap topographic radar data (also $5 \mathrm{~m}$ resolution) in ESRI ArcGIS to form a near-continuous onshore-offshore digital elevation model (Fig. 2). We use the term 'near-continuous' as there remains a narrow band of unsurveyed seabed within near-shore waters, typically in water less than 5-10 m depth where vessels were unable to access.

Glacigenic landforms at seabed were manually delineated using ESRI ArcGIS software, interpreted from the swath bathymetry and derived properties (hillshade, slope, rugosity). To assist interpretation the data were also analysed in a 3D visualization environment using Geovisionary software whereby illumination and other data presentation variables can be rapidly adjusted. Seabed landforms were mapped as polygons (delineating base of slope) rather than lines where possible to assist in morphometric analysis and to potentially examine morphometric variation along hypothesized glacial flow lines. This involved re-mapping some landforms previously presented in Howe et al. (2012) where many landforms were represented by lines only. Landforms were also divided into a simple compositional classification scheme (Bedrock and Bedrock dominated, Sediment and Sediment dominated) to potentially enhance our understanding of formation processes (Stokes et al., 2011), but also to ensure the wider applicability of the resulting seabed maps.

Landform composition was interpreted according to two primary criteria:

1- Where available, legacy BGS shallow seismic-profile data were consulted to determine whether landforms are sediment cored or bedrock cored, or a combination of the two (e.g. crag and tail). Examining the sub-bottom data allows for sub-seabed characteristics to be linked to seabed geomorphic signatures, thereby improving the confidence of our mapping where there is no shallow seismic data;

2- As closely spaced seismic lines have not been acquired in the region, the majority of landforms were mapped from the bathymetry data alone by analysing seabed morphology within the regional geological and hydrodynamic context. For example, sediment-cored landforms approximate theoretical forms(smoother, more symmetric), whereas bedrockcored structures are more irregular and influenced by local bedding and structural trends. 
211 Mapping was conducted at 1:10,000-1:20,000 scale, and is intended to be presented at 1:50,000

212 scale such that all significant features $(>50 \times 50 \mathrm{~m})$ have been captured (Tobler, 1988). Taking into

213 account that we are presenting a 'broad-scale' mapping effort, there remains significant unmapped

214 complexity at seabed that with further study will yield a more detailed understanding of past

215 processes.

\section{3. Results}

Mapping has revealed an extensive set of well-preserved glacigenic landforms on the seabed in the Inner Hebrides region of western Scotland (Figs. 4-7). And while the present study focuses on the glacial history of the region, many other non-glacial geomorphic features are observed on the bathymetric data including: widespread outcrops of ocean-current swept bedrock (Proterozoic through Cenozoic in age), (Fyfe et al., 1993); networks of large bedrock faults (Smith, 2012); fluidescape pockmarks in surficial sediments (Howe et al., 2012); and mobile sediment bedforms (e.g. sand waves) (Fig. 5). It is therefore necessary to distinguish between the glacigenic landforms of interest to this study and other seabed features, some of which may mimic the attributes of glacial forms, (e.g. mobile sediment waves, or bedrock outcrops with structures roughly parallel to former ice-flow directions).

\subsection{Kilometre-scale features}

The submarine sector of the Inner Hebrides exhibits variable bathymetric relief and several of the deepest basins inboard of the UK continental shelf break, including the Muck Deep at $320 \mathrm{~m}$ depth (Fig. 2). The broad-scale relief shows evidence of Palaeozoic-Cenozoic tectonic events acting upon rocks as old as $2 \mathrm{Ga}$ (e.g. Fyfe et al., 1993; Trewin, 2002; Smith, 2012; Howe et al., in press), while early Palaeogene volcanism has affected much of the region leaving a series of prominent, flat to gently westerly-dipping bedrock platforms (Fig. 2) (Emeleus and Bell, 2005; Browne et al., 2009). A detailed account of the complex bedrock and structural geology of the region is outside the scope of this paper, but it is worth noting that these basins and structures played a large part in controlling the flow and retreat dynamics of Quaternary glaciations, partially predetermining the locations of glacially overdeepened rock basins and troughs. In particular, EW trending joints (e.g. Muck Deep) and NNE-trending Mesozoic basins predisposed the glacial flow paths in the Sea of Hebrides south and west of the Great Glen Fault (Fig. 2) (Howe et al., 2012). It is likely that relative differences in pre-Cambrian Dalradian stratigraphy southeast of the Great Glen Fault governed the location and orientation of glacial overdeepening in the Firth of Lorn (Howe et al., in press) as well as the Sound of Jura. 


\subsection{Streamlined Landforms}

244 While the kilometre-scale erosional landforms (rock basins and troughs) signify the influence of glaciation in the region, they provide an ambiguous record of past ice-sheet behaviour (e.g. structurally biased orientation, formation over multiple glacial cycles). Mesoscale (tens of metres to

247 kilometres) streamlined features provide a more direct means of reconstructing past glacial flow

248 directions, and in certain circumstances ice-sheet dynamics. Across the study area we observe a

249 wide range of streamlined landforms, smooth and elongate, exhibiting both symmetric and 250 asymmetric forms (e.g. teardrop) (Figs. 4-7). Up to several kilometres in length, these streamlined 251 forms are preserved on multiple submarine rock platforms (e.g. Canna High (Fig. 6a)) and within overdeepened troughs where they are typically oriented parallel, or sub-parallel to dominant basin axes (e.g. Sound of Jura (Fig. 7)). From their seabed expression as well as acoustic character based on seismic data, the features may be formed of unlithified sediment or bedrock, or both. Sedimentonly features may reach $20 \mathrm{~m}$ in height with elongation ratios ranging from 2:1 to 10:1. Streamlined forms comprising some bedrock component may be up to $50 \mathrm{~m}$ in height, with elongation ratios commonly exceeding 10:1, though this is biased by structural trends in the underlying bedrock.

Morphologically similar to features observed elsewhere on the UK continental shelf (e.g. Bradwell et al., 2007) and on other formerly glaciated continental margins (e.g. Ottesen et al., 2005; Graham et al., 2009), we interpret these streamlined features as subglacial landforms, predominantly crag-and tails, drumlins, and flutings, elongated parallel to the direction of former ice-sheet flow (Stokes and Clark, 2001). Equivalent landforms have also been observed being formed and maintained under active ice streams (e.g. King et al., 2007). We have mapped over 2,000 streamlined landforms within the study area, which include sedimentary and bedrock forms.

\subsubsection{Interpretation of Landform Record - Streamlined Landforms}

266 The majority of the streamlined landforms within the study area are interpreted to represent ice

267 flow to the SW, particularly on the western margins of the study area (Fig.8: yellow arrows). Locally, 268 landforms exhibit a consistent orientation and are organized into clear flow sets. Where landforms 269 deviate from the dominant flow direction, further complexity of the ice sheet's flow history may be 270 inferred. Farther to the east and within terrestrially confined basins and fjords, landform orientation 271 is more variable, and more clearly topographically controlled (aligned to local basin axis) (Fig. 7). It is 272 also important to note that while streamlined sedimentary features explicitly reflect palaeo-ice 273 sheet flow direction, bedrock dominated features are predisposed by pre-glacial fracture and 274 bedding-plane orientation, and may represent a composite record of erosion imparted over multiple 
glacial cycles (e.g. Lane et al., 2014). For this reason, bedrock, and bedrock-dominated landforms are less reliable indicators of palaeo-flow direction.

In several places, multiple streamlined landforms are superimposed to form larger composite streamlined features, demonstrating that different landform types are frequently observed together within a particular area. This grouping of distinct landform types is frequently associated with changes in local physiographic and substrate conditions (e.g. relative position within a basin, or presence of bedrock at seabed). We find this relationship in general agreement with the observations by Stokes et al. (2011), who provide a systematic analysis of drumlins reported in the literature. Their resulting hypothesis is that variation in composition and geomorphology of subglacial drumlins within a particular terrain is more readily explained by a single glaciological process acting upon a variable substrate rather than multiple, distinct glaciological processes. Variation in drumlin character therefore often arises where formation mechanisms at the ice-bed interface interact with, and modify the pre-existing and variable surficial and shallow geology.

Large parts of the survey area are mantled by a variable thickness of glacimarine (Jura and Barra Formations) and Holocene sediment, particularly in deeper water away from coastlines and upstanding bedrock platforms (Fig. 3) (Davies et al., 1984; Fyfe et al., 1993; Howe et al., 2012). It is likely that many more landforms are buried beneath this post-glacial sediment, and thus not expressed on the swath bathymetry data. In fact, such features are observed on seismic lines seaward of the large drumlin field west of lona (Fig. 4). This evidence leads us to infer that the streamlined landforms observed at seabed are formed of subglacial sediments (where not eroded into bedrock) equivalent to the Hebrides Formation within the pre-existing regional seismostratigraphic framework. Underlying the Barra and Jura Formations, the Hebrides Formation (termed 'Minch Formation' by Boulton et al. (1981)) is a discontinuous coarse-grained diamict interpreted as subglacial till (Davis et al., 1984). Where present at seabed this diamict is likely very thin across the study area. Because of this, it is understandable how earlier investigations did not recognize glacigenic landforms in the seismic data, which is now possible due to the significant advantage afforded by cross-referencing 2D seismic profiles with the high-resolution bathymetry data (Howe et al., 2012; this study).

\subsubsection{Cross-cutting flow-sets}

Off the west coast of lona we observe two distinct flow sets of streamlined landforms, where a dominant SW directed flow set is superimposed by a later, less extensive SSW directed set (Fig. 4). This assemblage suggests ice-sheet reorganization over time, with different phases of fast flow at the ice-sheet bed (e.g. Stokes et al., 2009). The implication here is that the strong flow regime to the 
SW was decreased, evolving into a weaker, more localized SSW flow. The apparent diminishing and re-organization of the overriding ice mass indicates that the record of flow we are characterizing is probably associated with overall ice-sheet retreat.

\subsubsection{Convergent flow}

In Figure (5) we map a set of southerly directed drumlins converging on a more extensive trunk of larger streamlined landforms with a SW bearing. The landforms here indicate that ice over Coll/Tiree did not flow directly west across the low-relief topography (maximum elevation 140 m) of Tiree, but rather was drawn into the larger branch of SW directed flow, which extends to another large assemblage of landforms off lona (Fig. 4). A similar phenomena is observed on the Canna High, where westerly flow over the platform is deflected to the southwest as ice moves off the platform into a deeper trough within the Sea of Hebrides (Fig. 6a) (Howe et al., 2012). This convergence provides evidence that ice-sheet drainage was also organized into corridors of flow which acted to draw in further tributaries of ice.

\subsubsection{Depth Distribution of Streamlined Landforms}

When comparing the depth distribution of all mapped streamlined landforms together with the frequency distribution of bathymetry data $(\mathrm{m})$ across the survey area an interesting relationship emerges (Fig. 9). While landforms are found between $5 \mathrm{~m}$ and $250 \mathrm{~m}$ water depth, the majority lie between $25 \mathrm{~m}$ and $60 \mathrm{~m}$ water depth. One possible explanation for this apparent shallow water affinity is that the depth of landforms is simply a function of the variation in bathymetry across the area, i.e. most landforms fall between $25 \mathrm{~m}$ and $60 \mathrm{~m}$ because the majority of the seabed is at this depth interval. Indeed the frequency distributions (Fig. 9) demonstrate a clear relationship between the depth-distribution of landforms and the regional bathymetry, but there is a notable increase in the frequency of landforms (vs. bathymetry) observed between approximately $30 \mathrm{~m}$ and $50 \mathrm{~m}$ water depth. Visually we interpret this discrepancy to suggest other environmental variables are responsible for the depth of landforms, but to affirm this qualitative observation we conducted the Kolmogorov-Smirnov (K-S) test to examine the equality of the two distributions. The K-S test (Max D $=0.05>0.03=$ Critical D) confirms there is a statistical difference between the two. As such we invoke other mechanisms to explain the concentration of features between $30 \mathrm{~m}$ and $50 \mathrm{~m}$ and propose that preservation potential provides the most likely explanation.

As discussed in section 3.2.1, the glacially streamlined surface is very likely buried in deeper waters by post-glacial sediments, and we are confident that sediment burial is responsible for the relative dearth of landforms observed at seabed between $50 \mathrm{~m}$ and $100 \mathrm{~m}$ water depth. There is a near absence of landforms in water depths less than 20-25 m, which we tentatively attribute to wave 
erosion. Several locales within the Inner Hebrides exhibit extreme tidal flow (e.g. Corryvreckan), but as current strength is highly variable across the region, associated erosion is a geographically dependent process. We suggest that wave energy is the more dominant mechanism for erosion in shallow waters (i.e. $<25 \mathrm{~m}$ ). Waves disturb the seabed down to the wave base, the maximum depth at which surface waves may entrain seabed sediment. Wave base can be approximated as $1 / 2$ the lateral wave period, and with periods in the Hebrides between 6-8 secs ( 50-64 m) (Pantin, 1991; Sterl and Caires, 2005), this indicates the wave base is regionally around 25-32 m, which is consistent with our observations. This argument pre-supposes that the study area has been, on the whole, undergoing isostatic uplift since LGM at a greater rate than eustatic sea level rise (Shennan et al., 2000), and thus relative sea level has fallen, progressively subjecting glacigenic landforms to marine erosion. If this sea level model is not correct for the region (relative sea level was lower than present during some stage(s) since Late Pleistocene deglaciation), then potential sub- aerial weathering and marine transgression would be prime candidates for causing the observed nonuniform distribution of submarine glacial landforms.

\subsection{Ice-marginal Ridges}

\subsubsection{Moraines}

Superimposed on the glacially streamlined seabed are numerous sediment formed, irregular ridges which are commonly perpendicular or near perpendicular to adjacent or underlying streamlined landforms (where present) (Figs. 5-7). The ridges are most commonly observed on upstanding bedrock highs, or found lying transverse to neighbouring coastlines. The ridges are commonly 1-8 $\mathrm{m}$ high, approximately 50-100 $\mathrm{m}$ wide, and spaced between $500 \mathrm{~m}$ and $1 \mathrm{~km}$ apart. Although there is variation in size, spacing, and configuration of these landforms, we interpret them to be moraines, based on their affinity with ice-marginal features mapped on other formerly glaciated margins (Fig. 8) (Benn and Evans, 2014). In the northern part of the study area, several groups of moraines were previously described by Howe et al. (2012), and indicate 'pinned' glacial retreat along the coastlines of Skye and Rum. Farther south, moraines are found on a bedrock platform between Tiree and Mull (Fig. 5), off the west coast of Islay (Fig. 6b), and within the Sound of Jura (Fig. 7.).

\subsubsection{Interpretation of Landform Record - Moraines}

Offshore from Tiree, well preserved moraines record ice margin retreat to the northeast (Fig. 5). The configuration of these moraines varies according to local physiography, and they clearly overprint the underlying streamlined landforms as well as exposed bedrock at seabed, indicating a more recent formation. 
373 Offshore from Islay, ice margin retreat has had a more destructive effect on the pre-existing

374 landform assemblage, depositing multiple small arcuate moraines that appear to deform the 375 underlying streamlined landforms (Fig. 6b). Similar to the moraines off Rum and Skye (oriented

376 normal to the adjacent coastlines) these moraines suggest 'pinned' ice margin retreat, in this case 377 along the broad bedrock platform between Islay, and Colonsay to the North (Fig. 2). An alternative 378 interpretation is that these transverse ridges could be ribbed moraines, thereby associated with ice 379 flow, and potentially inter-related with ice streaming and the surrounding drumlins (e.g. Dunlop and 380 Clark, 2006).

381

382

Along of the Sound of Jura we find a well preserved series of approximately trough-perpendicular, equally spaced ridges ( $\sim 1 \mathrm{~km}$ ) which we interpret as recessional moraines (Fig. 7). Evenly distributed between these moraines are further sets of smaller, minor transverse ridges which appear similar in form and spacing (50-100 $\mathrm{m}$ ) to De Geer moraines, which are indicative of sub-aqueous deposition (Fig . 7 - inset) (e.g. Todd et al., 2007). This landform assemblage together with the convex 'upglacier' inclination across the trough, and the over-deepened bathymetry of the Sound of Jura leads us to suggest that ice-sheet retreat occurred here along a tidewater margin, grounded in the shallows, potentially with small ice shelves extending over deeper water (e.g. Ottensen \& Dowdeswell, 2006). As elsewhere within the study area, these moraines overprint the glacially streamlined landscape. In places the De Geer moraines sit atop the relative high of the drumlinized forms, but not surrounding areas, thus delineating the streamlined shape. This again raises the alternative hypothesis that the ridges could instead be ribbed moraines. We would argue however that this mimicry is a consequence of preservation rather than origin (draping hemi-pelagic deposition within relative deeps), and that the orientation of the minor transverse ridges, which mirrors that of the larger recessional moraines, is more compatible with ice margin retreat, than the preceding ice streaming events.

\subsubsection{Sinuous Ridges}

At a number of locations (e.g. Figs. 4, 6a), we observe narrow sinuous ridges (3-5 m high, 100 m wide) with rounded crests. The ridges are often bifurcated and found on localized bathymetric highs, commonly atop eroded streamlined landforms. Ridge profiles appear smoother, and morphologically distinct from other moraines in the region, and ridge orientations are incongruent with expected ice margin retreat patterns (i.e. recession broadly towards hinterland). Howe et al. (2012) tentatively interpret the features on the Canna High as moraines, but we alternatively suggest they may be eskers, deposited by glaciofluvial processes near the retreating ice margin. While the identification of eskers in a submarine setting is relatively rare (e.g. Todd et al., 2007), the orientation of the ridges (sub-parallel to underlying streamlined landforms) here is perhaps more 
compatible with this hypothesis than a morainic origin. Unfortunately, we have no ground-truthing data from these features to determine ridge composition, so further work is required to ascribe an origin to these features.

\section{Discussion}

On multiple submarine rock platforms and within overdeepened troughs, assemblages of glacially streamlined landforms and superimposed ice-marginal landforms provide a clear record of flow, and subsequent ice-sheet retreat across the region (Fig. 8). The occurrence of glacigenic landforms is controlled in varying degrees by the geology, topography, and water depth (elevation control on preservation potential), however these factors alone cannot account for the location, orientation, and pattern of the observed landforms. We consider the geomorphic evidence together with previous findings to draw inferences about the regional flow and retreat dynamics of the BIIS within the Inner Hebrides, and extrapolate these interpretations out towards the shelf.

\subsection{Hebrides Ice Stream - Onset and ice stream pathways}

Apart from the more isolated assemblages observed within topographically confined, fjord-like basins in the east of the study area (e.g. Sound of Jura (Fig. 7)), streamlined landforms are found across the region within a geographically controlled zone: an approximately north-south oriented belt along the western margin of the Inner Hebrides (Fig. 8). We interpret that this notable concentration ice-flow indicators is consistent with the hypothesis of Howe et al. (2012) that an ice stream drained this sector of the BIIS, and that the head of this ice stream system was located within the Inner Hebrides. It is also consistent with ice-sheet modelling studies that predict multiple phases of streaming flow originating in the region (e.g. Boulton and Hagdorn, 2006; Hubbard et al., 2009). With new bathymetry data greatly increasing the archive of mapped ice-flow indicators in the region, we amend the previously proposed zone(s) of ice stream onset (Howe et al., 2012) as well as reconstruct the regional flow patterns associated with the Hebrides Ice Stream (Fig. 8).

The observed north-south oriented belt of streamlined landforms frequently corresponds to the margin between bedrock platforms in the east, and sediment-filled troughs to the west (Figs. 2,8). We suggest that within the proposed onset zone, convergent ice movement transitioned from 'sheet flow' to 'streaming flow' as ice travelled from the rugged hinterland, accelerating out across the smooth sediment dominated shelf, establishing a stable flow pattern over time (e.g. King et al., 2007; Bradwell et al., 2007; De Angelis and Kleman, 2008). While many argue that drumlins and other streamlined landforms result from the relatively fast flow of ice over its bed (e.g. Stokes and Clark, 2001; Ó Cofaigh et al., 2005), others suggest drumlins may only signify ice travelling 
consistently along a continuous flow path, i.e. fast flow is not required (e.g. Winsborrow et al., 2010). We don't seek to address this debate with the newly presented data, but rely on the consensus that streamlined landforms in rock and soft sediment reflect the coherent flow of ice over its bed.

The eastern margin of the proposed ice stream onset zone is characterized by a sharp decline in streamlined landforms observed from west to east across the area (Fig. 8). This supports the glaciodynamic interpretation for the origin of this decline, as this boundary shows no consistent correlation with substrate geology, water depth, or observable landform erosion/burial. Streamlined landforms are observed on, and eroded into multiple bedrock types throughout the study area (e.g. Tertiary Basalt - Canna (Fig. 6a); Dalradian metasedimentary rocks - Sound of Jura (Fig. 7)). Although some local bedrock types and structural characteristics (e.g. bedding plane strike) appear more conducive to preserving geomorphic evidence of glaciation (Figs. 4-7), the concentration of streamlined landforms along the north-south belt appears semi-independent of the variations in bedrock lithology (Fyfe et al., 1993). For example, east of Coll there is a sharp decline in landforms from southwest to northeast where there is no corresponding change in bedrock type, and no change to the extent of bedrock exposed at seabed (i.e. no obscuring sediment cover) (Fig. 8). Further to this, water depths across this boundary (declining landforms to northeast) are consistently greater than $25 \mathrm{~m}$, therefore the seabed should not be disproportionately impacted by the marine erosion which is found to inhibit preservation of shallow landforms elsewhere in the study area (Section 3.2.1.3) (Figs. 9).

We extend the eastern limit of onset within several broad bathymetric troughs (e.g. SE of the Canna High) as we expect these seabed deeps would have served as topographic pathways focussing icesheet flow (Figs. 2, 8). This interpretation remains tentative though as some troughs are filled with over $100 \mathrm{~m}$ of post-glacial sediment (Fyfe et al., 1993) covering any potential geomorphic evidence. This same phenomenon makes the western margin of the onset zone more difficult to constrain, as the streamlined glacial surface generally dips to greater depths towards the west, becoming progressively obscured by post-glacial sediment (Section 3.2.1) (Figs. 3,9). Revisiting legacy 2D seismic data to investigate the sub-surface could improve our understanding, but it may require 3D seismic to confidently identify characteristic features along (multiple?) buried horizons (e.g. Graham et al., 2007).

While ice stream onset provides the most satisfactory explanation for the geographic distribution of streamlined landforms along the western margin of the Inner Hebrides, topography (acting at different scales) appears to be the primary influence on the orientation of the observed landforms. 
472 Within the proposed Hebrides Ice Stream onset zone, landform orientation appears to be

473 independent of local-scale topography (i.e. feature orientation largely insensitive to dominant slopes 474 within $\sim-10 \mathrm{~km}$ ), but significantly influenced by the regional topographic setting (10s $-100 \mathrm{~s} \mathrm{kms})$

475 (Figs. 1,8). Looking southwest from the projected glacial flow paths it becomes apparent how 476 regional-scale topography played a role in governing ice-sheet flow dynamics (e.g. Winsborrow et 477 al., 2010) (Fig. 8). The Lewisian Skerryvore Bank southwest from Coll and Tiree separates two broad, 478 structurally-controlled troughs which are further interrupted to the west by the Stanton Banks. 479 Observed ice flow signatures within the onset zone are directed towards (e.g. west of Mull), or 480 aligned according (e.g. deflected flow vectors off the Canna High) to the axes of these large troughs which are carved up to $200 \mathrm{~m}$ below the surrounding seabed. This indicates that ice stream tributaries within the Inner Hebrides were influenced by, and ultimately drawn into these larger branches of the ice-sheet drainage network out towards the continental shelf, at least for the period when the observed streamlined features were formed. Further illustrating this influence, the convergence of a smaller ice stream tributary (southerly bearing flow-set) being drawn into a larger branch (SW bearing) southeast of Tiree demonstrates that streaming was probably also organized into conduits of relatively slower and faster flow, or at least tributaries of lesser or greater dominance (Fig. 5). This flow configuration also suggests that the bedrock platform incorporating Coll and Tiree likely served as an ice-sheet 'sticky' spot (e.g. Stokes et al., 2007), where flow was retarded by the protruding 'islands' relative to the fast-flow regimes established to the north and south within the troughs. Taking account of the accumulated geomorphic evidence and regional physiography, we propose that the two large troughs hosted dominant branches of the composite Hebrides Ice Stream, where streaming initiated along the western margin of the Inner Hebrides (onset zone), merged along a medial line between Tiree and the Stanton Banks, and directed flow across the Malin Shelf towards the Barra-Donegal Trough-Mouth Fan (Fig. 8).

\subsection{Hebrides Ice Stream - Wider Implications}

497 We have identified and described a well-constrained strongly convergent ice-sheet flow configuration that accommodated drainage within a significant sector (5-10\%) of the BIIS. We are aware however that the observed landform record likely represents only a limited time interval and may not be representative of maximal glacial conditions. Empirical observations from other sectors

501 (e.g. Bradwell et al., 2008; Scourse et al., 2009) as well as ice sheet-wide modelling studies (e.g.

502 Hubbard et al., 2009) indicate a complex and dynamic evolution of the BIIS during the Late 503 Pleistocene, with varying spatial flow configurations adopted over multiple growth and decay cycles. 504 Across the Inner Hebrides region, several recent studies suggest ice-sheet flow (mass flux and direction) differed dramatically between full glacial conditions when grounded ice reached the 
continental shelf break, and more reduced glacial conditions when the ice-sheet was thinner and more constrained by local topography (Dunlop et al., 2010; Clark et al., 2012, Finlayson et al., 2014).

508 Future investigations of the sub-surface, and the refinement of the glacial seismic stratigraphy (Fig. 3) are required to place the observed seabed record of glaciation into context with potentially preceding Late Weichselian ice streaming events, as well as pre-Weichselian glacial periods.

511 A further consideration for understanding the evolution of the Scottish-based ice mass within the 512 Inner Hebrides is how it interacted with Irish-based ice, and ice occupying the Irish Sea basin (e.g. 513 Greenwood and Clark, 2009). The apparent sensitivity to migrating ice divides in the region 514 influenced flow configurations over time, leading to regional fluctuations that may have been asynchronous with overall mass-balance changes of the BIIS (e.g. Finlayson et al., 2014; Hughes et al., 2014). For example, an advancing Irish Sea Ice Stream would draw-down areas of ice that otherwise may have flowed west towards the Barra-Donegal Trough-Mouth Fan (Fig. 1) (e.g. Clark et al., 2012; Chiverell et al., 2013). Indeed Dunlop et al. (2010) observe a series of glacigenic landforms on the Malin Shelf indicating periods of confluence, and alternating dominance of Scottish vs. Irishbased ice. Like Dunlop et al. (2010), we interpret that during full glacial conditions ( 27-23 ka; Peck et al., 2007; Scourse et al., 2009) the Hebrides Ice Stream would have merged with the North Channel-Malin Shelf Ice Stream issuing from parts of south-west Scotland, the Irish Sea basin, and Ireland (e.g. Greenwood and Clark, 2009; Finlayson et al., 2014) to form the composite 'Barra Fan Ice Stream' system which ultimately reached the shelf margin (Fig. 8) (e.g. Stoker et al., 1994; Ó Cofaigh et al., 2012).

We would argue that a similar flow configuration (as described above) could have existed during maximal glacial conditions as the large degree of regional-scale topographic control appears sufficient to accommodate drainage for this sector of the LGM BIIS. Reconstructions and modelling studies support this hypothesis (e.g. Boulton and Hagdorn, 2006; Hubbard et al., 2009; Hughes et al., 2014), though the exact configuration would be further dependent on factors like the relative influences of the North Channel-Malin Shelf ice stream, ice thickness over north-eastern Ireland, and the semi-independent ice mass centred on the Outer Hebrides (Fig. 1) (e.g. Stone and Ballantyne, 2006). For example, a smaller ice mass on the Outer Hebrides would have allowed a more westerly component to flow, but the apparent topographic steering of mainland ice to the southwest may have rendered this ice-buttressing effect insignificant. 
flow indicators (Fig. 5), cross-cutting flow sets (Fig. 4), and divergent flow indicators (Fig. 6b), are signatures more indicative of a thinning ice mass undergoing reorganization as part of an overall, but punctuated retreat (e.g. Conway et al., 2002; Stokes et al., 2009). Further supporting this interpretation, ice flow indicators ( $\sim$ SW bearing) offshore Islay show no influence from the North Channel-Malin Shelf Ice Stream, which is proposed to have been directed to the WNW, and confluent with the HIS during full glacial conditions (Fig. 8) (Greenwood and Clark, 2009; Dunlop et al., 2010). Terrestrial observations (including the orientation of glacial landforms, transport directions of erratics, and glacial striations) from Kintyre, Arran, Islay, and Jura also suggest that during maximal glacial conditions, these land masses were over-run by ice, with flow directed to the WNW (Synge and Stephens, 1966; Dawson, 1997; Cousins, 2012; Finlayson et al. 2014). Thick ice, coupled with drawdown towards large western troughs, is likely to have diminished the influence of local topography, enabling the westerly flow direction of ice.

Taken together, the location and orientation of streamlined glacigenic landforms provide evidence of a large ice stream (HIS) delivering ice from the Inner Hebrides out towards the Malin Shelf, but nuances in the pattern of these landforms suggest that this streaming probably occurred during a period of ice-sheet reorganization and overall retreat. Under this regime, we interpret that the progressive reconfiguration of the ice sheet would have resulted the abandonment and/or migration of flow pathways, with flow vectors increasingly constrained by local-scale topography as the ice mass thinned. As the landforms remain well preserved at seabed, and are frequently overprinted by normally oriented moraines (Figs. 5, 8), we infer this represents the last activity of the HIS prior to ice retreating to more isolated, topographically confined fjords. Retreat from the shelf towards and into the Inner Hebrides may have been rapid due the prevalence of overdeepened troughs which would have facilitated accelerated retreat, via tide-water margins retreating into deeper water (e.g. Todd et al., 2007; Jamieson et al., 2012).

\subsection{Subsequent Confined flow and retreat.}

East, and farther landward of the proposed HIS onset zone we observe other, though fewer (excluding the Sound of Jura) assemblages of glacially streamlined landforms within isolated, topographically confined troughs and basins. Primarily aligned with local basin axes, the orientation of these landforms is more strongly controlled by topography than those attributed to the HIS, and thus more variable across the region (Fig. 8). We interpret these landforms to have formed following the collapse of the HIS as ice pulled back into smaller tributaries and fjords where the stable flow of thinner, topographically partitioned ice masses was temporarily re-established (e.g. Clark and Meehan, 2001). 
572 We interpret the overprinting of recessional moraines atop the streamlined landforms (both types 573 well preserved at seabed) to suggest that retreat began after the cessation of ice streaming within 574 these confined basins. And while we present no new absolute chronological data to constrain this 575 transition or the rate of retreat, an extensive series of recessional moraines within the Sound of Jura 576 provides geomorphic evidence on the style of this retreat. The recessional moraines are further 577 subdivided by evenly spaced minor transverse ridges, which taken together indicate a rhythmic 578 retreat up the fjord (Fig. 7). As we have interpreted these minor transverse ridges as De Geer 579 moraines, and recognizing the overdeepened bathymetry of the Sound of Jura, we hypothesize that 580 retreat likely occurred along tidewater margins (e.g. Todd et al., 2007). A radiocarbon age from the

581 Sound of Jura, published by Peacock (2008), indicates that ice retreat was complete by $13.1{ }^{14} \mathrm{C}$ ka BP

582 (approximately 15 cal ka BP). Moraines observed elsewhere in the study area are commonly 583 oriented normal to adjacent landmasses (e.g. Skye, Rum), indicating punctuated glacial retreat as the 584 regions complex topography provides multiple 'pinning points' to temporarily stabilize ice-sheet 585 margins during late-stage retreat from the marine environment (e.g. Favier et al., 2012).

586 There remains a paucity of Pleistocene chronological data from the marine environment around the 587 Inner Hebrides, and we do not present new age data here. Dating the deglaciation of this ice-sheet 588 sector forms part of a wider research programme, which is currently underway (Clark et al., 2014). 589 Instead, we have attempted to place our observations into a relative chronological framework, 590 making comparisons with other regional observations and utilising existing ice-sheet reconstructions 591 and ice-sheet modelling experiments. We find that our observations of the streaming phase of the 592 HIS, and subsequent retreat to confined positions within the fjords where further flow and retreat is 593 recorded, are broadly consistent with the spatial reconstructions proposed by Finlayson et al. (2014). 594 Applying their event timescale implies the HIS was active from approximately 32-17 ka, though 595 probably underwent significant fluctuations in mass-flux and spatial extent during this period (e.g. 596 peak: 27-23 ka (Scourse et al., 2009; Finlayson et al., 2014)). With HIS break up around 17-16.5 ka, 597 the ice-sheet would then have retreated to the confined fjords and basins of the Inner Hebrides 598 where final marine influenced retreat occurred between approximately $16.5 \mathrm{ka}$ and $16 \mathrm{ka}$ (Fig. 8).

600 We identify and map approximately 2,200 glacigenic landforms relating to spatially variable ice601 sheet flow, and ice margin retreat of the last British-Irish Ice Sheet (BIIS) within the submarine 602 environment of the Inner Hebrides, Scotland. Illustrating the value of extensive, high-resolution 603 swath bathymetry data for the purposes of palaeoglaciology, the interpreted geomorphic record has 
significant implications for understanding the pattern and timing of Late Pleistocene ice-sheet flow, reorganization, and decay for a large sector (5-10\%) of the BIIS.

Streamlined landform assemblages (both bedrock and sediment-dominated) indicate the coherent flow pattern of a grounded ice-sheet, probably within the upper reaches (onset zone) of the Hebrides Ice Stream. The spatial distribution of landforms left behind by the Hebrides Ice Stream demonstrates the significant influence of regional-scale topography in governing the configuration of ice-sheet flow in this region, an affect which is particularly notable at the terrestrial-to-marine transition. This work also provides important insight for understanding how the Hebrides Ice Stream would have interacted with Irish-based, and further Scottish-based ice issuing from the Irish Sea when the ice masses were confluent. Suites of morainic landforms indicate numerous still-stands or minor ice-marginal advances during overall ice-sheet thinning and retreat. The retreat of the marinedominated Hebrides Ice Stream may have been rapid, as has been suggested for neighbouring marine-influenced sectors of the ice-sheet (such as the Minch ice stream to the north) (Bradwell \& Stoker, 2015). Initial rapid retreat was probably followed by more punctuated ice-front retreat around the rugged islands and topographically pronounced headlands fjords and basins where stable flow was temporarily re-established. Further decay, and final ice-sheet retreat from the marine environment was likely achieved within the glacially overdeepened fjords along tidewater margins.

Empirically derived reconstructions such as this are particularly important for understanding the retreat history and dynamics of marine-based, or strongly marine-influenced ice sheets like the former British-Irish Ice Sheet as the terrestrial record alone may provide incomplete, or ambiguous evidence of deglaciation. This work further highlights the high preservation potential of landforms in a submarine setting, and the importance of acquiring extensive seismic (sub-surface) data to provide complimentary three-dimensional perspectives. We also explore poorly understood aspects of

627 landform preservation in the marine environment (e.g. post-glacial sedimentation-landform burial and marine erosion) that may bias our interpretations where aspects like relative sea level change are not well constrained over time. And although the excellent bathymetric data have enabled a detailed reconstruction of past ice-sheet dynamics, chronological control is lacking in this region, and further sampling and dating of glacigenic material is required to test the hypotheses presented here.

\section{Acknowledgements:}

633 Bathymetry data provided courtesy of the Maritime \& Coastguard Agency's UK Civil Hydrography 634 Programme (C) Crown copyright. Terrestrial topography data derived from Intermap Technologies 635 NEXTMap Britain elevation data. Dayton Dove, Andrew Finlayson, and Tom Bradwell publish with 636 the permission of the Executive Director, British Geological Survey (NERC). The research leading to 
these results has received funding from the People Programme (Marie Curie Actions) of the discussions on the pre-Quaternary geology of the region.

\section{References}

Andreassen, K., Laberg, J. S., Vorren, T. O., 2008. Seafloor geomorphology of the SW Barents Sea and its glacidynamic implications. Geomorphology 97 (1), 157-177.

Bamber, J. L., Vaughan, D. G., Joughin, I., 2000. Widespread complex flow in the interior of the Antarctic ice sheet. Science 287 (5456), 1248-1250.

Benn, D., \& Evans, D. J., 2014. Glaciers and glaciation. Routledge.

Bennett, M.R., 2003. Ice streams as the arteries of an ice sheet: their mechanics, stability and significance. Earth-Science Reviews 61 (3), 309-339.

Binns, P. E., 1974. Glacial and postglacial sedimentation in the Sea of the Hebrides. Nature 248, 751-754.

Boulton, G. S., Chroston, P., Jarvis, J., 1981. A marine seismic study of late Quaternary sedimentaion and inferred glacier fluctuations along western Inverness-shire, Scotland. Boreas 10 (1), 39-51.

Boulton, G., Hagdorn, M., 2006. Glaciology of the British Isles Ice Sheet during the last glacial cycle: form, flow, streams and lobes. Quaternary Science Reviews 25, (23), 3359-3390.

Bradwell, T., Stoker, M., Larter, R., 2007. Geomorphological signature and flow dynamics of The Minch palaeo-ice stream, northwest Scotland. Journal of Quaternary Science 22, (6), 609-617.

Bradwell, T., Stoker, M.S., Golledge, N.R., Wilson, C.K., Merritt, J.W., Long, D., Everest, J.D., Hestvik, O.B., Stevenson, A.G., Hubbard, A.L., Finlayson, A.G., Mathers, H.E., 2008. The northern sector of the last British Ice Sheet: maximum extent and demise. Earth-Science Reviews 88 (3), 207-226.

Bradwell, T., 2013. Identifying palaeo-ice-stream tributaries on hard beds: Mapping glacial bedforms and erosion zones in NW Scotland. Geomorphology 201, 397-414.

Bradwell, T., Stoker, M.S., 2015. Submarine sediment and landform record of a palaeo-ice stream within the British-Irish Ice Sheet Boreas 44 (2), 255-276.

British Geological Survey, 1987. Tiree: Quaternary Geology, 1:250 000 Series. (Keyworth, Nottingham: British Geological Survey).

Browne, D.J., Holohan, E.P., Bell, B.R., 2009. Sedimentary and volcano-tectonic processes in the British Paleocene Igneous Province: a review. Geological Magazine 146 (3), 326-352.

Calder, B. R., Mayer, L. A., 2003. Automatic processing of high-rate, high-density multibeam echosounder data. Geochemistry, Geophysics, Geosystems 4 (6), DOI: 10.1029/2002GC000486.

Chiverrell, R.C., Thrasher, I.M., Thomas, G.S.P., Lang, A., Scourse, J.D., Van Landeghem, K.J.J., McCarroll, D., Clark, C.D., O'Cofiagh, C., Evans, D.J.A., Ballantyne, C.K., 2013. Bayesian modelling the retreat of the Irish Sea ice stream. J. Quat. Sci. 28, 200-209.

Clark, C. D., 1997. Reconstructing the evolutionary dynamics of former ice sheets using multi-temporal evidence, remote sensing and GIS. Quaternary Science Reviews 16(9), 1067-1092.

Clark, C.D., Meehan, R.T., 2001. Subglacial bedform geomorphology of the Irish Ice Sheet reveals major configuration changes during growth and decay. Journal of Quaternary Science 16 (5), 483-496.

Clark, C. D., Hughes, A. L. C., Greenwood, S. L., Jordan, C., Sejrup, H. P., 2012. Pattern and timing of retreat of the last British-Irish Ice Sheet. Quaternary Science Reviews 44, 112-146.

Clark, C. D., Fabel, D., Ó Cofaigh, C., Chiverrell, R., Scourse, J., Hindmarsh, R. C. A., Bradwell, T., Evans, D. J. A., Benetti, S.,Freeman, S., Moreton, S., Ballantyne, C., Bateman, M. D., Bigg, G. R., Burke, M., Davies, S., Duller, G., Greenwood, S., Gregoire, L.,Hambrey, M., Hughes, A., Jamieson, S., Livingstone, S., McCarroll, D., McCarron, S., Monteys, X., Pienkowski, A., Praeg, D., Roberts, D., Rutt, I., Sejrup, H. P., Small, D., van Landeghem, K., 2014. BRITICE-CHRONO: constraining rates and style of marineinfluenced ice sheet decay. Quaternary Revolutions; Quaternary Research Association, Annual Discussion Meeting, London. Abstract Volume, p. 16.

Conway, H., Catania, G., Raymond, C.F., Gades, A. M., Scambos, T. A., Engelhardt., H., 2002. Switch of flow direction in an Antarctic ice stream. Nature 419 (6906), 465-467.

Cousins, R., 2012. The Glaciation History of Islay: Implications for Ice Sheet Dynamics in South-west Scotland (unpublished BSc thesis). University of Edinburgh. 
Davies, H. C., Dobson, M. R., \& Whittington, R. J., 1984. A revised seismic stratigraphy for Quaternary deposits on the inner continental shelf west of Scotland between $55^{\circ} 30^{\prime} \mathrm{N}$ and $57^{\circ} 30^{\prime} \mathrm{N}$. Boreas, 13(1), 49-66.

Dawson, A.G., 1982. Lateglacial sea-level changes and ice-limits in Islay, Jura and Scarba, Scottish Inner Hebrides. Scottish Journal of Geology 18 (4), 253-265.

Dawson, A.G., 1997. Medial moraine (Sgriob na Caillich), western Jura. In Dawson, A. G. and Dawson, S. (eds.), 1997, Islay and Jura: Field Guide. Quaternary Research Association, Cambridge.

De Angelis, H., Kleman, J., 2008. Paleo-ice-stream onsets: examples from the northeastern Lauretide ice sheet. Earth Surface Processes and Landforms 33, 560-572.

Dunlop, P., Clark, C. D., 2006. The morphological characteristics of ribbed moraine. Quaternary Science Reviews 25 (13), 1668-1691.

Dunlop, P., Shannon, R., McCabe, M., Quinn, R., Doyle, E., 2010. Marine geophysical evidence for ice sheet extension and recession on the Malin Shelf: new evidence for the western limits of the British-Irish Ice Sheet. Marine Geology 276, 86-99.

Emeleus, C. H., \& Bell, B. R., 2005. The Palaeogene volcanic districts of Scotland. $4^{\text {th }}$ edition. British Geological Survey, (British Regional Geology, 3), Nottingham, UK, 214pp.

Favier, L., Gagliardini, O., Durand, G., Zwinger, T., 2012. A three-dimensional full Stokes model of the grounding line dynamics: effect of a pinning point beneath the ice shelf. The Cryosphere 6, 101-112.

Favier, L., Durand, G., Cornford, S. L., Gudmundsson, G. H., Gagliardini, O., Gillet-Chaulet, F., Zwinger, T., Payne, A.J., Le Brocq, A. M., 2014. Retreat of Pine Island Glacier controlled by marine ice-sheet instability. Nature Climate Change, 4(2), 117-121.

Finlayson, A., Fabel, D., Bradwell, T. \& Sugden, D. 2014. Growth and decay of a marine terminating sector of the last British-Irish Ice Sheet: a geomorphological reconstruction. Quaternary Science Reviews 83, 2845.

Fyfe, J.A., Long, D., Evans, D., 1993. The Geology of the Malin-Hebrides Sea Area. HMSO for the British Geological Survey, London.

Geikie, A., 1863. On the phenomena of the glacial drift of Scotland. Transactions of the Geological Society of Glasgow 1, 1-190.

Graham, A. G. C., Lonergan, L., Stoker, M. S., 2007. Evidence for Late Pleistocene ice stream activity in the Witch Ground Basin, central North Sea, from 3D seismic reflection data. Quaternary Science Reviews 26 (5), 627-643.

Graham, A. G., Larter, R. D., Gohl, K., Hillenbrand, C. D., Smith, J. A., Kuhn, G., 2009. Bedform signature of a West Antarctic palaeo-ice stream reveals a multi-temporal record of flow and substrate control, Quaternary Science Reviews 28 (25), 2774-2793.

Greenwood, S.L., Clark, C.D., 2009. Reconstructing the last Irish Ice Sheet 2: a geomorphologically-driven model of ice sheet growth, retreat and dynamics. Quaternary Science Reviews 28 (27), 3101-3123.

Gregory, J.W., 1927. The fiords of the Hebrides. Geographical Journal, 193-212.

Harkness, D. D., Wilson, H., 1974. Scottish Universities Research and Reactor Centre radiocarbon measurements II. Radiocarbon 16 (2), 238-251.

Howe, J. A., Dove, D., Bradwell, T. \& Gafeira, J. 2012. Submarine geomorphology and glacial history of the Sea of the Hebrides, UK. Marine Geology 315, 64-76.

Howe, J. A., Anderton, R., Arosio, R., Dove, D., Bradwell, T., Crump, P., Cooper, R., Cocuccio, A., (in press). The seabed geomorphology and geological structure of the Firth of Lorn, western Scotland, UK. Proceedings of the Royal Soceity of Edinburgh.

Hubbard, A., Bradwell, T., Golledge, N., Hall, A., Patton, H., Sugden, D., Cooper, R., Stoker, M., 2009. Dynamic cycles, ice streams and their impact on the extent, chronology and deglaciation of the British-Irish ice sheet. Quaternary Science Reviews 28 (7), 758-776.

Hubbard, B., Glasser, N.F., 2005. Field techniques in glaciology and glacial geomorphology. Wiley.

Hughes, A. L., Clark, C. D., Jordan, C. J., (2014). Flow-pattern evolution of the last British Ice Sheet. Quaternary Science Reviews 89, 148-168.

Jakobsson, M., Andreassen, K., Bjarnadóttir, L.R., Dove, D., Dowdeswell, J.A., England, J.H., Funder, Hogan, K., Ingólfsson, Ó., Jennings, A., Larsen, N.K., Kirchner, N., Landvik, J.Y., Mayer, L., Mikkelsen, N., Möller, P., Niessen, F., Nilsson, J., O'Regan, M., Polyak, L., Nørgaard-Pedersen, N., Stein, R., 2014. Arctic Ocean glacial history. Quaternary Science Reviews 92, 40-67.

Jamieson, S.R., Vieli, A., Livingstone, S.J., Ó. Cofaigh, C., Stokes, C., Hillenbrand, C.D., Dowdeswell, J.A., 2012. Ice-stream stability on a reverse bed slope. Nature Geoscience 5 (11), 799-802.

King, E.C., Woodward, J., Smith, A.M., 2007. Seismic and radar observations of subglacial bed forms beneath the onset zone of Rutford Ice Stream, Antarctica. Journal of Glaciology 53 (183), 665-672. 
Knutz, P.C., Austin, W.E.N., Jones, E.J.W., 2001. Millennial-scale depositional cycles related to British Ice Sheet variability and North Atlantic paleocirculation since 45 kyr B.P., Barra Fan, UK margin. Paleoceanography 16, 53-64.

Lane, T.P., Roberts, D.H., Rea, B.R., Ó. Cofaigh, C., Vieli, A., 2014. Controls on bedrock bedform development beneath the Uummannaq Ice Stream onset zone, West Greenland. Geomorphology 231, 301-313.

Ó Cofaigh, C.O., Dowdswell, J.A., Allen, C.S., Hiemstra, J.F., Pudsey, C.J., Evans, J., Evans, D.J.A., 2005. Flow dynamics and till genesis associated with a marine-based Antarctic palaeo-ice stream. Quaternary Science Reviews 24, 709-740.

Ó Cofaigh, C., Dunlop, P., Benetti, S., 2012. Marine geophysical evidence for late Pleistocene ice sheet extent and recession off northwest Ireland. Quaternary Science Reviews 44, 147-159.

Ottesen, D., Dowdeswell, J. A., Rise, L., 2005. Submarine landforms and the reconstruction of fast-flowing ice streams within a large Quaternary ice sheet: The 2500-km-long Norwegian-Svalbard margin (57-80 N). Geological Society of America Bulletin 117 (7-8), 1033-1050.

Ottesen, D., Dowdeswell, J. A., 2006. Assemblages of submarine landforms produced by tidewater glaciers in Svalbard. Journal of Geophysical Research 111 F01016, doi:10.1029/2005JF000330.

Pantin, H. M., 1991. The sea-bed sediments around the United Kingdom: their bathymetric and physical environment, grain size, mineral composition and associated bedforms. British Geological Survey Research Report, SB/90/1. 47pp.

Peacock, J. D., Horne, D. J., Whittaker, J. E., 2012. Late Devensian evolution of the marine offshore environment of western Scotland. Proceedings of the Geologists' Association, 123 (3), 419-437.

Peck, V.L., Hall, I.R., Zahn, R., Grousset, F., Hemming, S.R., Scourse, J.D., 2007. The relationship of Heinrich events and their European precursors over the past 60 ka BP: a multi-proxy ice-rafted debris provenance study in the north east Atlantic. Quaternary Science Reviews 26, 862-875.

Pollard, D., DeConto, R. M., 2009. Modelling West Antarctic ice sheet growth and collapse through the past five million years. Nature 458 (7236), 329-332.

Scourse J. D., Haapaniemi A. I., Colmenero-Hidalgo E., Peck V. L., Hall I. R., Austin W. E. N., Knutz P. C., Zahn R., 2009. Growth, dynamics and deglaciation of the last British-Irish ice sheet: the deep-sea ice-rafted detritus record. Quaternary Science Reviews (28), 3066-3084.

Sejrup, H.P., Hjelstuen, B.O., Dahlgren, K.I.T., Haflidason, H., Kuijpers, A., Nygard, A., Praeg, D., Stoker, M.S., Vorren, T.O., 2005. Pleistocene glacial history of the NW European continental margin. Marine and Petroleum Geology 22, 1111-1129.

Shennan, I., Lambeck, K., Horton, B., Innes, J., Lloyd, J., McArthur, J., Purcel, T., Rutherford, M., 2000. Late Devensian and Holocene records of relative sea-level changes in northwest Scotland and their implications for glacio-hydro-isostatic modelling. Quaternary Science Reviews 19 (11), 1103-1135

Sissons, J. B., 1983. The Quaternary geomorphology of the Inner Hebrides: a review and reassessment. Proceedings of the Geologists' Association 94 (2), 165-175.

Smith, K., 2012. The Fascadale fault: a tectonic link between the Cenozoic volcanic centres of Rum and Ardnamurchan, Scotland, revealed by multibeam survey. Scottish Journal of Geology 48 (2), 91-102.

Sterl, A., Caires, S., 2005. Climatology, variability and extrema of ocean waves: the Web-based KNMI/ERA-40 wave atlas. International Journal of Climatology 25 (7), 963-977.

Stoker, M. S., Leslie, A. B., Scott, W. D., Briden, J. C., Hine, N. M., Harland, R., Wilkinson, I.P., Evans, D., Ardus, D. A., 1994. A record of late Cenozoic stratigraphy, sedimentation and climate change from the Hebrides Slope, NE Atlantic Ocean. Journal of the Geological Society 151 (2), 235-249.

Stokes, C. R., Clark, C. D., 2001. Palaeo-ice streams. Quaternary Science Reviews 20 (13), 1437-1457.

Stokes, C.R., Clark, C.D., Lian, O.B., Tulaczyk, S., 2007. Ice stream sticky spots: a review of their identification and influence beneath contemporary and palaeo-ice streams. Earth-Science Reviews 81 (3), 217-249.

Stokes, C.R., Clark, C.D., Storrar, R., 2009. Major changes in ice stream dynamics during deglaciation of the north-western margin of the Laurentide Ice Sheet. Quaternary Science Reviews 28 (7), 721-738.

Stokes, C.R., Spagnolo, M., Clark, C.D., 2011. The composition and internal structure of drumlins: Complexity, commonality, and implications for a unifying theory of their formation. Earth-Science Reviews 107, (3), 398-422.

Stone, J.O., Ballantyne, C.K., 2006. Dimensions and deglacial chronology of the Outer Hebrides Ice Cap, northwest Scotland: implications of cosmic ray exposure dating. Journal of Quaternary Science 21, (1), 75-84.

Synge, F.M., Stephens, N., 1966. Late- and post-glacial shorelines, and ice limits in Argyll and north-east Ulster. Trans. Inst. Br. Geogr. 39, 101-125. 
Tobler, W., 1988. Resolution, resampling and all that. In Mounsey, H. and Tomlinson, R. (eds), Building Databases for Global Science. Taylor and Francis, London, pp. 129-137.

Todd, B.J., Valentine, P.C., Longva, O., Shaw, J., 2007. Glacial landforms on German Bank, Scotian Shelf: evidence for Late Wisconsinan ice-sheet dynamics and implications for the formation of De Geer moraines.Boreas 36 (2), 148-169.

Trewin, N. H. (Ed.), 2002. The geology of Scotland (4 ${ }^{\text {th }}$ Edition). Geological Society of London.

Truffer, M., \& Echelmeyer, K. A., 2003. Of isbrae and ice streams. Annals of Glaciology 36 (1), 66-72.

Winsborrow, M., Clark, C.D., Stokes, C.R., 2010. What controls the location of ice streams? Earth-Science Reviews 103 (1), 45-59.

\section{Figure captions:}

1) Regional bathymetry with Inner Hebrides study area delineated in red. Palaeoglaciological reconstruction modified from Howe et al. (2012) where hypothesized ice stream flow paths and trough mouth fan extents were derived from Stoker et al. (1995), Sejrup et al. (2005), Bradwell et al. (2007), Scourse et al. (2009), and Dunlop et al. (2010). Proposed LGM limit taken from Bradwell et al. (2008). Ice stream onset zones proposed by Howe et al. (2012) are shown in blue (observed landforms) and orange (hypothesized) shading. Hebrides Ice Stream (HIS); Minch Ice Stream (MIS); Barra Donegal Fan (BDF); Sula SgeirFan (SSF). Bathymetry from GEBCO and BGS DigBath@NERC.

2) High-resolution swath bathymetry data from the Inner Hebrides study area combined with NEXTMap digital terrain model. Insets for Figures 3-6 indicated by black boxes. Bathymetry data provided courtesy of the Maritime \& Coastguard Agency's UK Civil Hydrography Programme (C) Crown copyright. Terrestrial topography data derived from Intermap Technologies NEXTMap Britain elevation data.

3) Quaternary seismic stratigraphy according to Davies et al. (1984) and Fyfe et al. (1993). This simplified stratigraphic diagram is presented along an arbitrary E-W profile, and is modified from British Geological Survey (1987). Interpreted formation ages remain tentative due to sparse chronological control in the region.

4) A) Bathymetry data from offshore lona reveal assemblage of glacially streamlined landforms and several superimposed sinuous ridges of ambiguous origin (possible moraines or eskers). Inferred glacial flow paths indicated by white arrows. B) Inset box reveals cross-cutting flow sets of streamlined landforms where the dominant SW directed flow set (white arrows) is superimposed by a later, less extensive SSW directed set (black arrows). C) Interpreted glacigenic landforms from panel (A) area, with slightly thickened landform outlines drawn for clarity. See Fig. 2 for location.

5) A) Bathymetry data from offshore Tiree reveal assemblage of glacially streamlined landforms and recessional moraines overlying broad bedrock platform with bedding planes and deformational fabric apparent at seabed. Convergence of streamlined landforms in the west suggests ice streaming was organized into corridors of slower and faster flowing ice (white arrows). Moraines indicate regular retreat to the northeast. B) Interpreted glacigenic landforms from panel (A) area, with slightly thickened landform outlines drawn for clarity. See Fig. 2 for location. 
6) A) Bathymetry from broad bedrock platform southwest of Canna reveal assemblage of glacially streamlined landforms and several superimposed sinuous ridges of ambiguous origin (possible moraines or eskers) (Howe et al., 2012). Inferred glacial flow paths indicated by white arrows. Note that the orientation of streamlined landforms changes towards the west, suggesting flow was deflected by a larger ice stream flowing SSW. B) Bathymetry data from offshore Islay reveal assemblage of streamlined landforms and recessional moraines. Streamlined landforms appear to have been deformed by the retreating ice margin. Interpreted glacigenic landforms shown in insets for both panel areas A) and B), with slightly thickened landform outlines drawn for clarity. See Fig. 2 for location.

7) A) Bathymetry data from the Sound of Jura reveal assemblage of glacially streamlined landforms and moraines overlying commonly exposed bedrock strata. Inferred glacial flow paths indicated by white arrows. Inset panel B) shows series of smaller transverse ridges distributed between larger recessional moraines. These are interpreted as De Geer moraines. C) Interpreted glacigenic landforms from panel (A) area, with slightly thickened landform outlines drawn for clarity. See Fig. 2 for location.

8) Interpreted geomorphological map and regional glaciological reconstruction illustrating key phases of ice flow and ice-margin retreat based on glacigenic landforms observed at seabed. Observed features and interpreted characteristics are described in the legend, and overlie the high-resolution study-area bathymetry presented in gray-scale and the regional bathymetry in blue-scale.

9) Depth distribution of streamlined landforms. The depth $(\mathrm{m})$ of all mapped landforms (black columns) compared with bathymetry (gray) (sub-sampled to $50 \mathrm{~m}$ cells) across the entire study area. To enable comparison between the two, frequencies were normalized to percentage (number of samples within given depth interval $(5 \mathrm{~m}) /$ total number of samples (mapped landforms $\approx 1700$ samples; bathymetric cells $\approx 75,000$ samples)). Note the increase in mapped landforms (vs. bathymetry) between $30 \mathrm{~m}$ and $50 \mathrm{~m}$. Tentative explanations to explain this difference are given for deeper $(50-100 \mathrm{~m})$ and shallower $(<30 \mathrm{~m})$ waters. 
Click here to download high resolution image

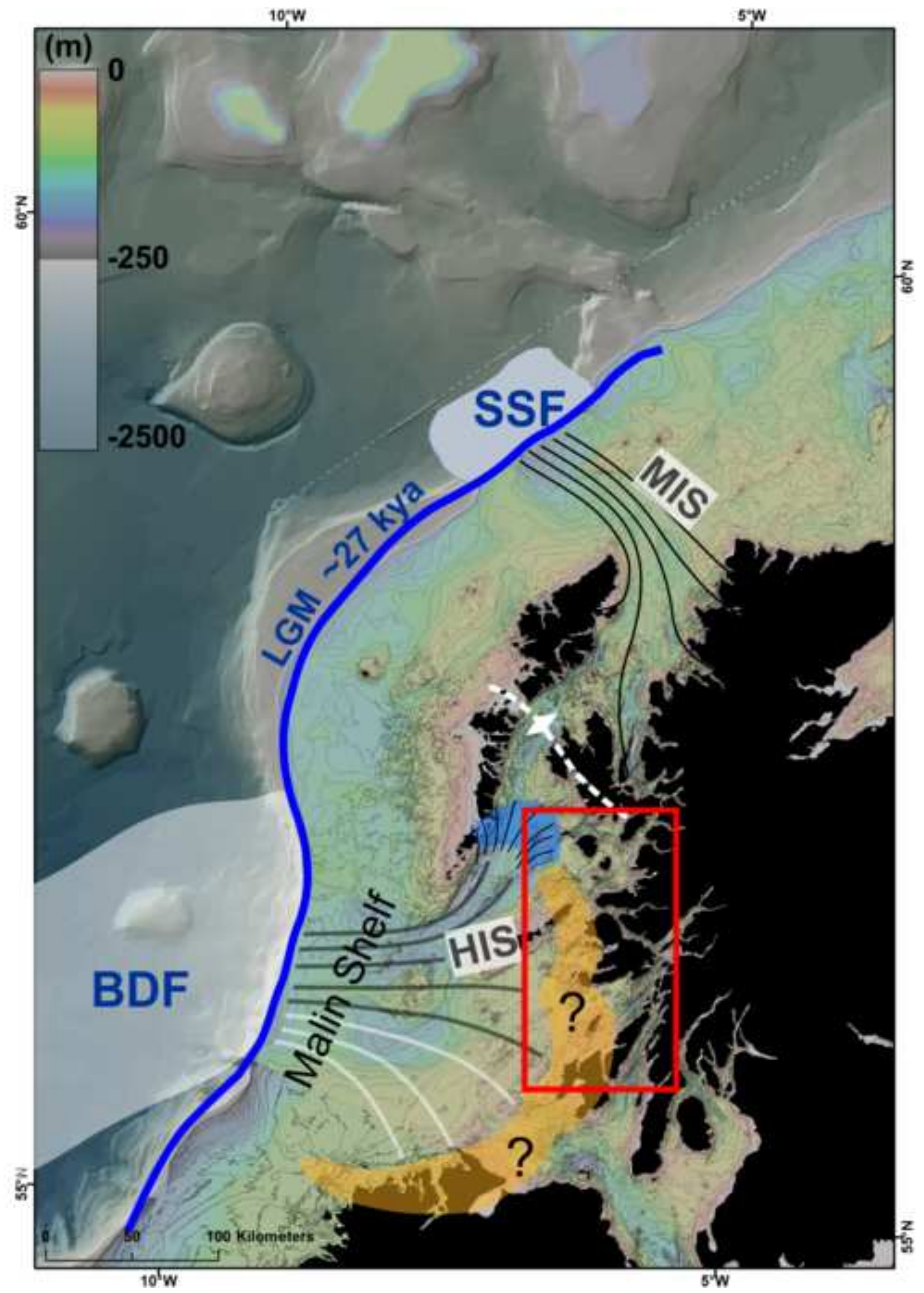


Figure2
Click here to download high resolution image

Figure2
Click here to download high resolution image
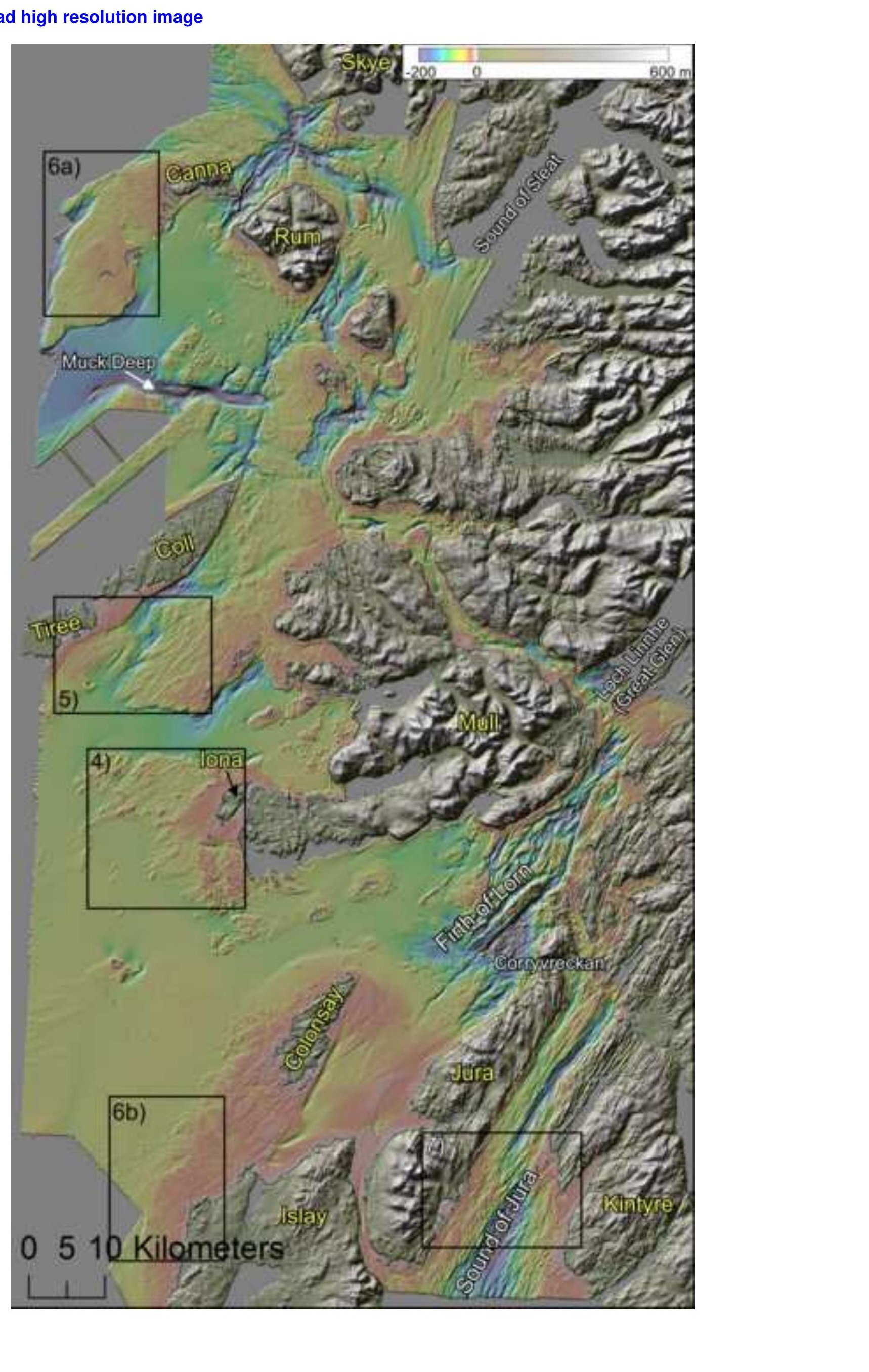


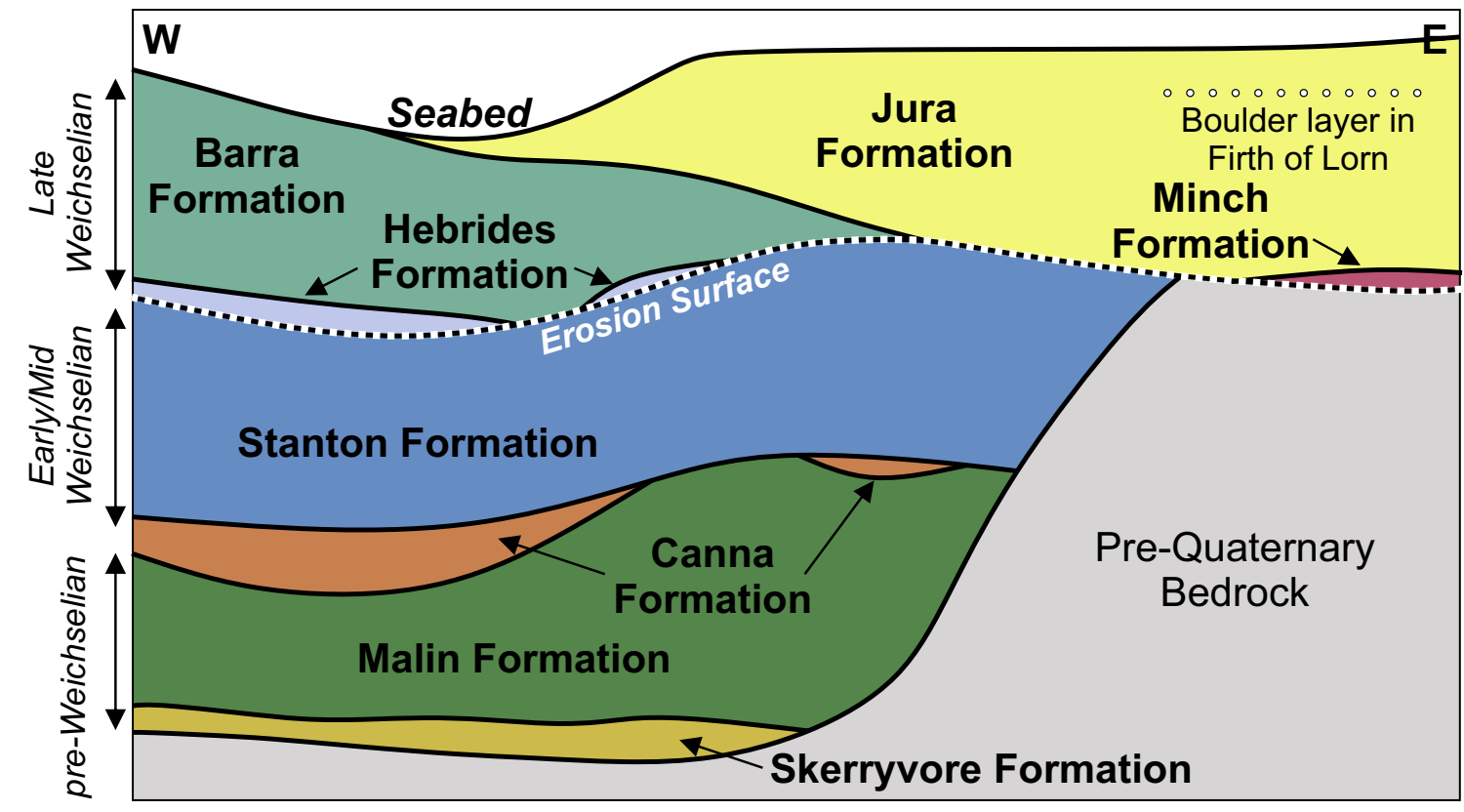

$\frac{8}{d}$
0
0
$\frac{0}{0}$

Intepreted Late Weichselian Formations (Davies et al., 1984; Fyfe et al., 1993)

Jura Fm. - Complex glacimarine to marine silty Clay

Barra Fm. - Glacimarine silty Clay with dropstones

Hebrides/Minch Fms. - Glacial till of coarse-grained diamict 


\section{Figure4}

Click here to download high resolution image

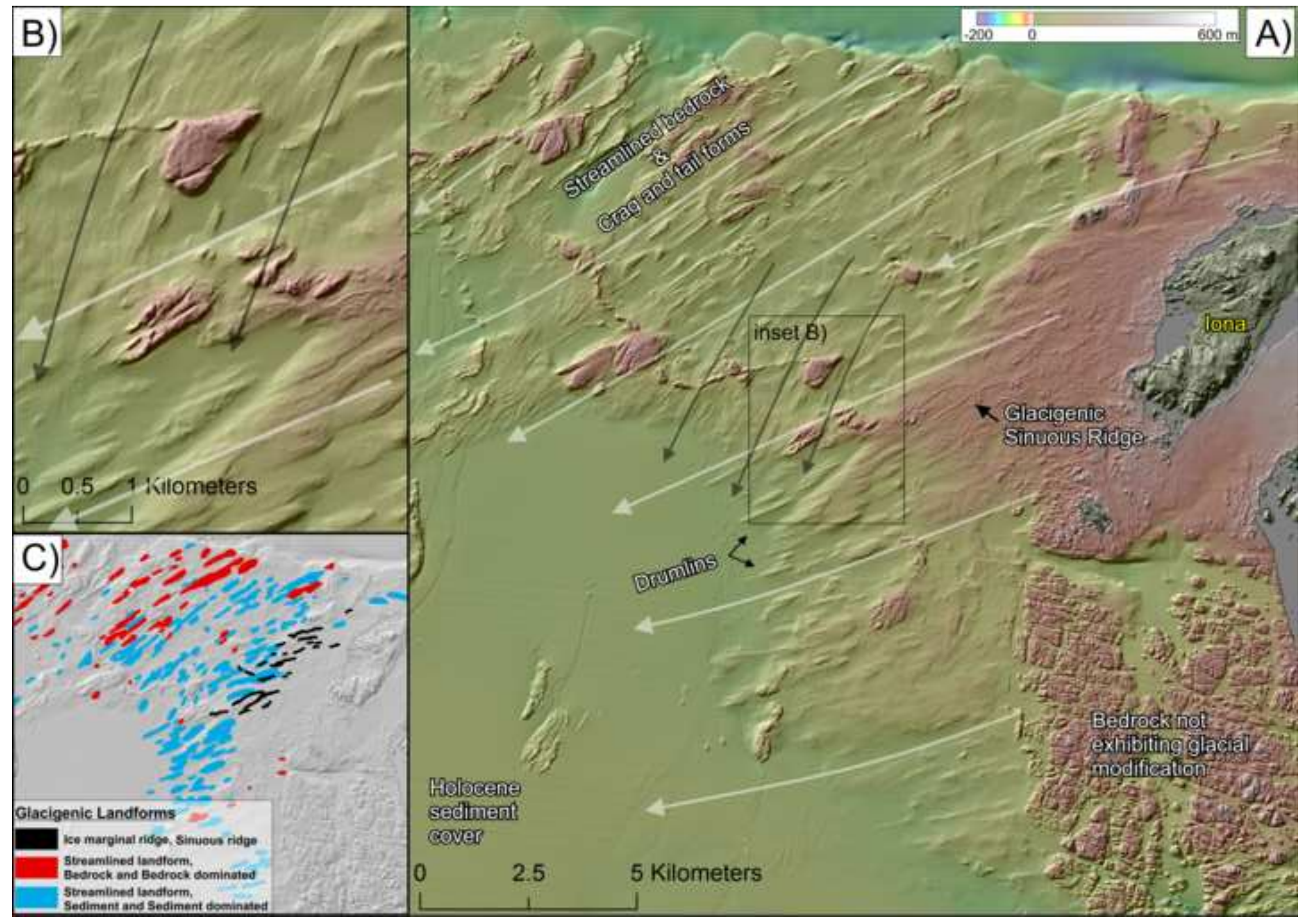




\section{Figures}

Click here to download high resolution image
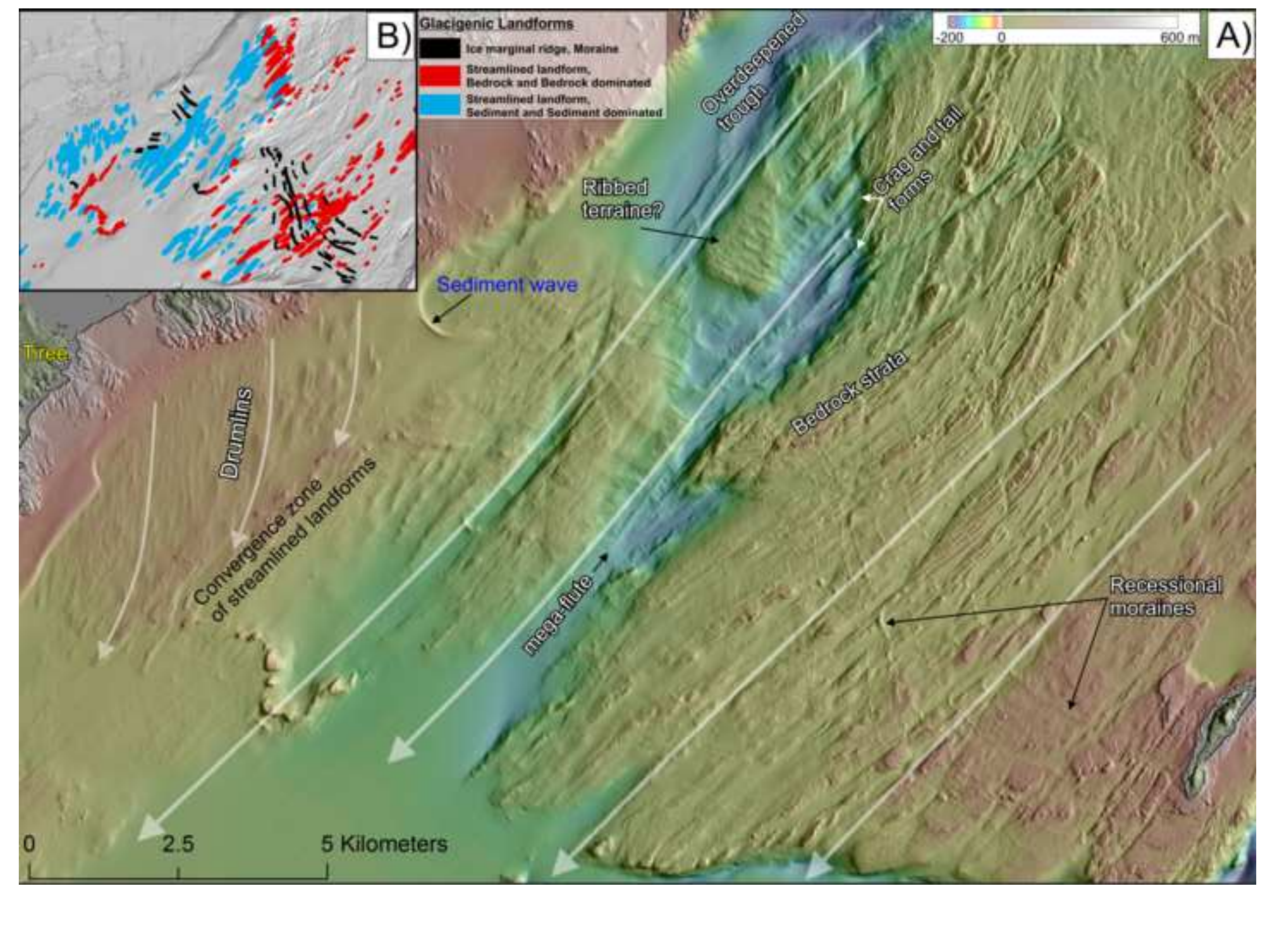


\section{Fure}

Click here to download high resolution image

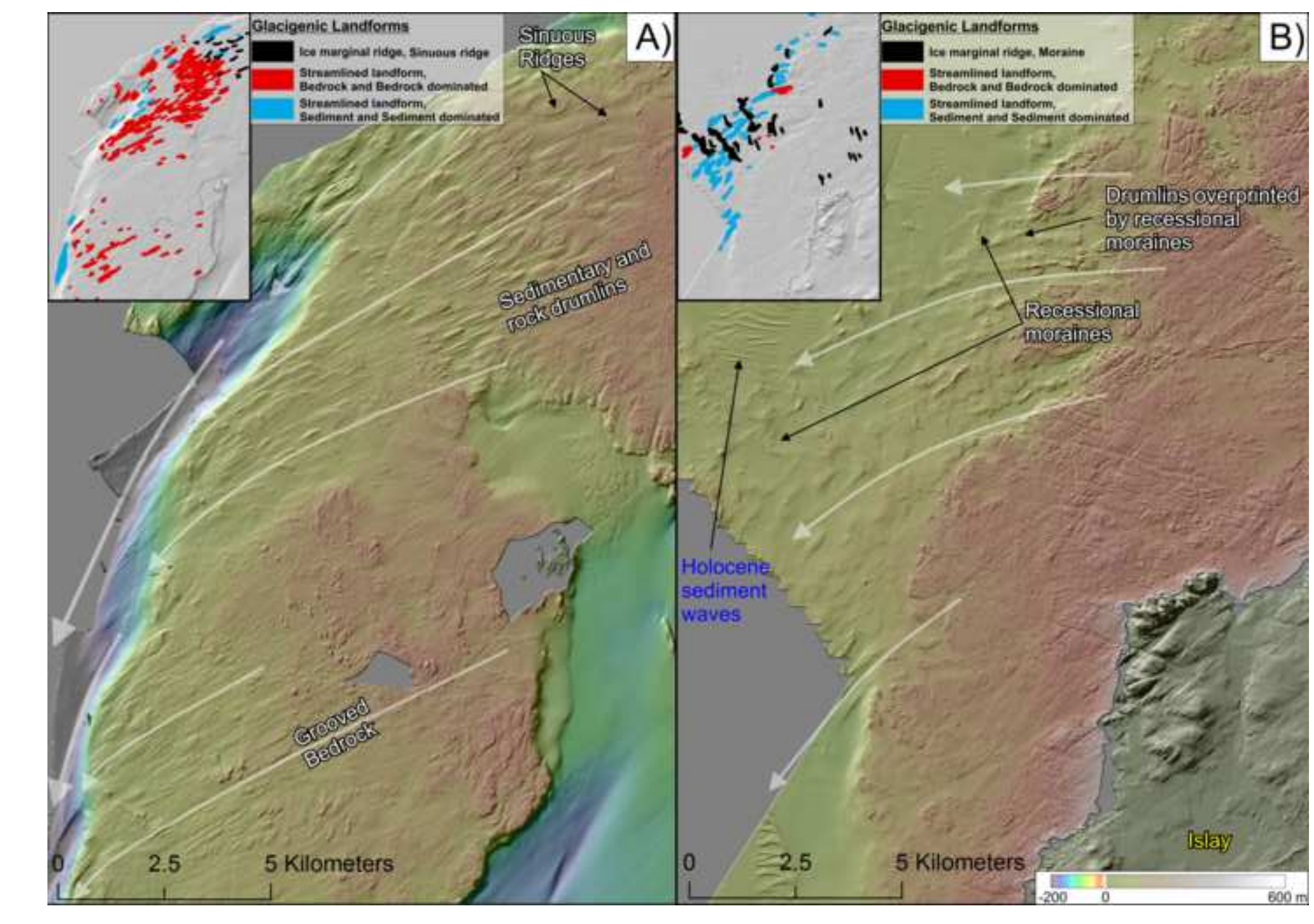


Click here to download high resolution image

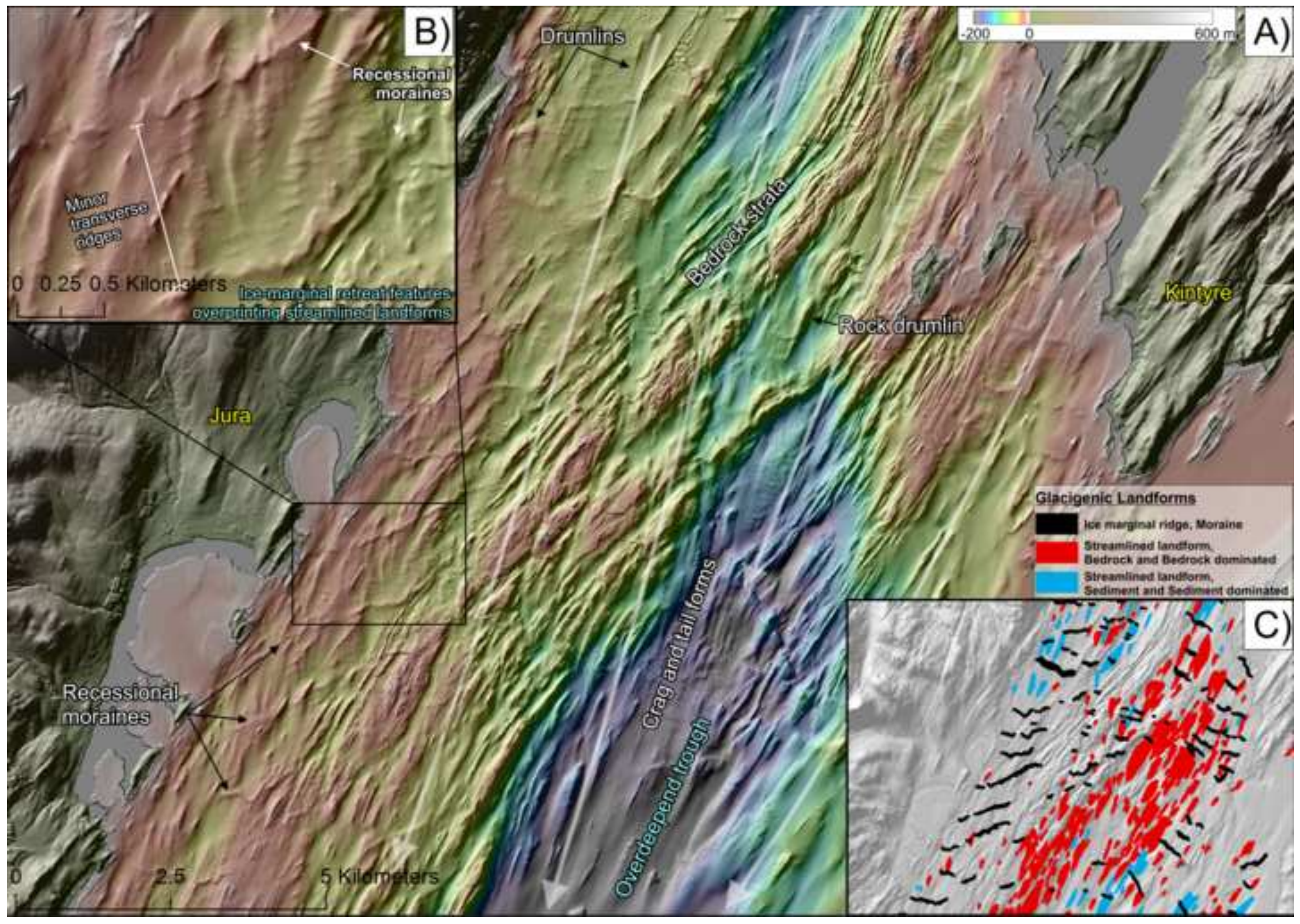


Figure8
Click here to download high resolution image

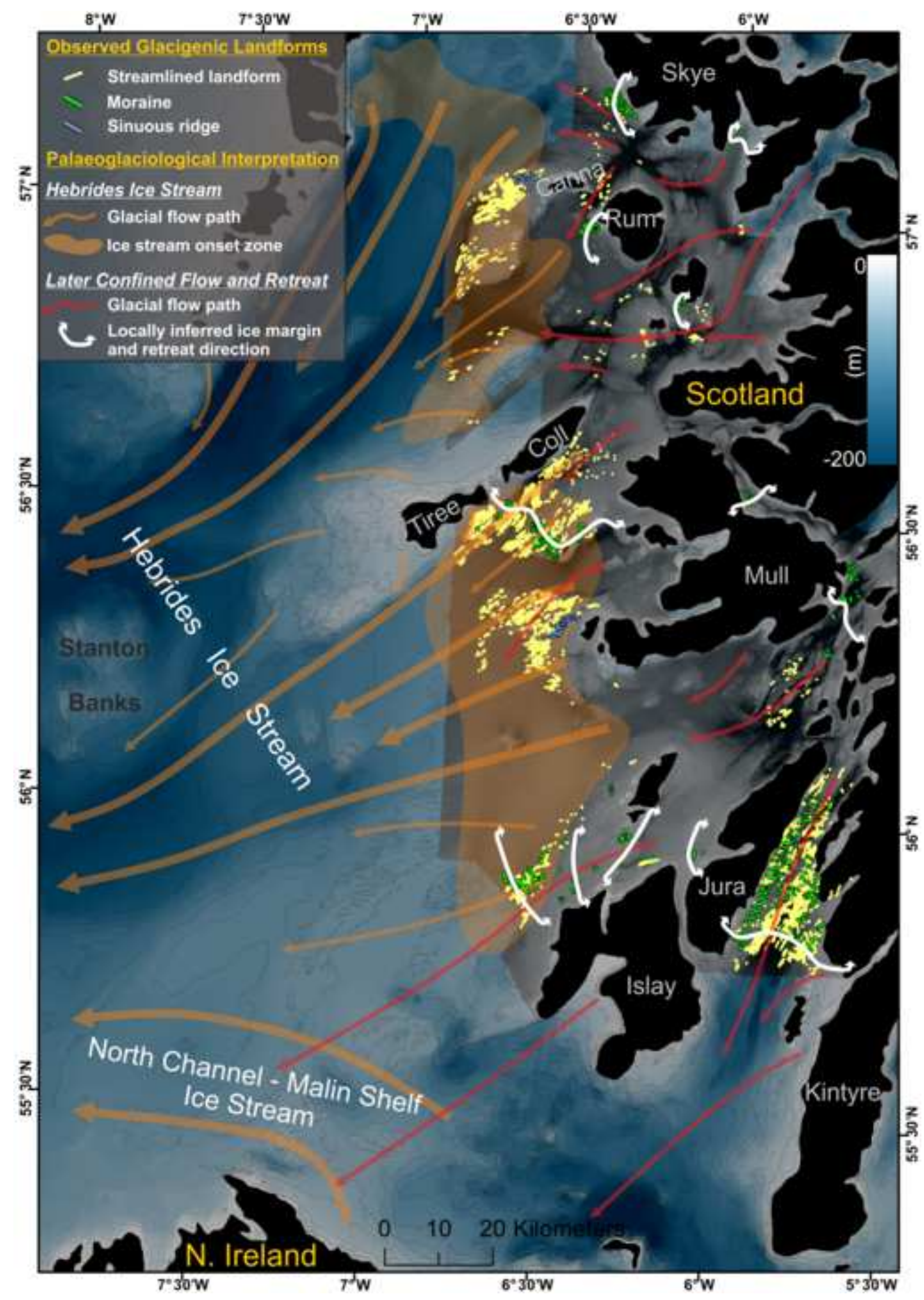


$\square$ Bathymetry $\quad$ Observed Landforms

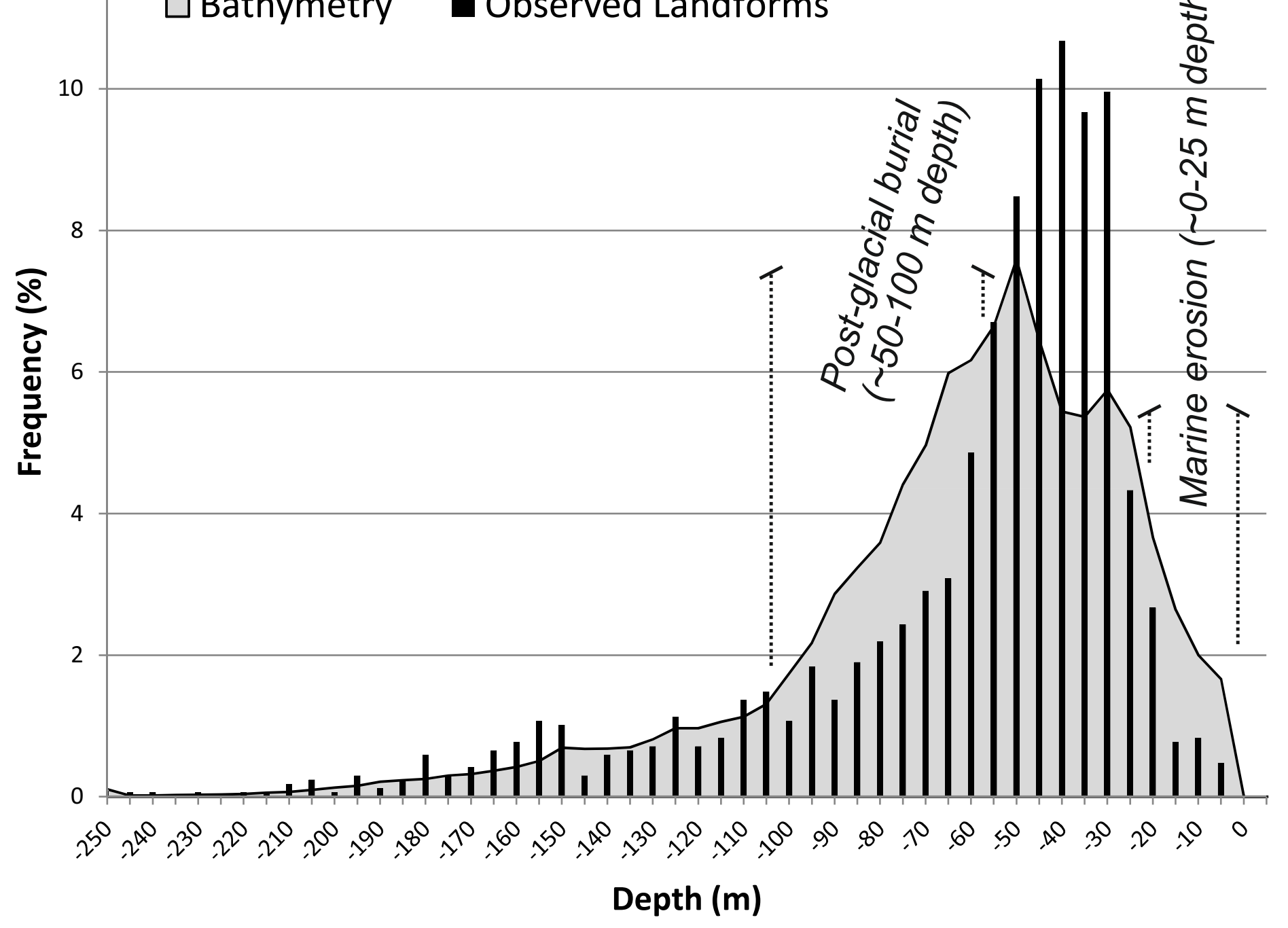

